\title{
Zâtî’nin Manzum Kasîde-i Bürde Tercümesi
}

\section{Poetic Translation Of Qasidat Al-Burda By Zâtî}

\author{
Damla Taşdelen ${ }^{1}$ (1)
}

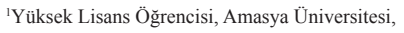
Sosyal Bilimler Enstitüsü Türk Dili ve Edebiyatı Bölümü, Amasya, Türkiye

\section{ORCID: D.T. 0000-0001-6648-3090}

Sorumlu yazar/Corresponding author: Damla Taşdelen,

Amasya Üniversitesi, Sosyal Bilimler Enstitüsü Türk Dili ve Edebiyatı Bölümü, Amasya, Türkiye E-mail: dktasdelen@gmail.com

Başvuru/Submitted: 30.04 .2020

Revizyon Talebi/Revision Requested: 06.05.2020 Son Revizyon/Last Revision Received: 15.05.2020 Kabul/Accepted: 15.05 .2020

\section{Atıf/Citation:}

Tasdelen, D. (2020). Zâtî'nin Manzum Kasîde-1 Bürde tercümesi. TUDED 60(1), 113-152. https://doi.org/10.26650/TUDED2020-0026

\section{ÖZET}

Bu çalışmada, Muhammed b. Sa id el-Bûsirî’nin hicrî 7. yüzyılda Arapça olarak kaleme aldığ1 el-Kevâkibü'd-dürriyye fì medhi hayri'l-beriyye adlı manzumesinin Türkçe tercümelerinden biri ele alınacaktır. İmam Bûsirî'nin Hz. Muhammed'e duyduğu derin muhabbetin ürünü olan ve literatürde Kasîde-i Bürde olarak tanınan 161 beyitlik kasîdesi, bu eksende yazılmış en güzel naat örneklerinden biri olarak kabul edilmiştir. Tüm İslam dünyasında müstesna bir yere sahip olan Kasîde-i Bürde; İngilizce, Farsça, Fransızca ve Urduca gibi pek çok dile çevrilmiş, Türk kültür ve edebiyatına da derinden tesir ederek manzum veya mensur olarak defalarca tercüme ve şerh edilmiştir. Üzerinde çalışıı̆ımız Milli Kütüphane 06 Yz. A 859/9 numaralı mecmuada 31b-44a varakları arasında bulunan manzum Kasîde-i Bürde nüshası da bu tercümelerden biridir. Eserin mütercimi, Zâtî mahlaslı bir şairdir. Ancak bu Bürde tercümesinin, XVI. yüzyılın ünlü şairi Zâtî’ye mi yoksa asıl adı Süleymân olan Keşanlı Zâtî’ye mi ait olduğu hakkında kesin bir hüküm verilememektedir. Bununla birlikte makalede temas edilen bazı hususlardan ötürü Süleymân Zâtî’ye ait olduğu fikri ağır basmaktadır. Bu makalede öncelikle Bûsirî ile Kasîde-i Bürde'sine ve kasîdenin Türkçe șerh ve tercümelerine değinilmiştir. Ardından söz konusu müelliflerin hayatları, sanatları ve eserleri hakkında bilgi verilmiştir. Son olarak şekil ve çeviri özellikleri açısından değerlendirilerek tercümenin metni sunulmuştur. Anahtar Kelimeler: Zâtî, Bûsirî, Kasîde-i Bürde, tercüme, manzum

\section{ABSTRACT}

In this study, a Turkish translation of Al-Kawākib ad-Durrīya fì Madh Khayr al-Barīya originally written in Arabic by Muhammed bin Sa id al-Bûsirî in the $7^{\text {th }}$ century is addressed. The one hundred and sixty one couplet qasida was the outcome of the great interest of Imam Bûsirî for Prophet Mohammad, and known as Qasidat al-Burda in literature, has been accepted as one of the most beautiful examples of eulogy in this field. The Qasidat al-Burda, having exceptional value in the world of Islam, was translated into many languages including English, Persian, French, and Urdu. Additionally, it deeply influenced the Turkish culture and literature and was translated and explained in verse or prose many times. As the subject matter of this study, a copy of the poem Qasidat al-Burda, between the sheets of 31b-44a in the journal numbered as 06 Yz. A 859/9 in National Library, is one of those translations. The translator of the work was a poet having the appellative "Zâtî". However, it has not been established whether this translation of Burda belonged to the famous poet Zâtî of the $15^{\text {th }}$ century or Zâtî from Keşan whose real name was Süleymân. Due to some issues dealt with in the article, the idea that it belonged to Süleymân Zâtî has the highest probability. In this article, firstly Bûsirî and his Qasidat al-Burda, the Turkish explanations, and translations of the qasida are examined. Afterwards, the lives, art, and works of the aforementioned authors are analyzed. Lastly, the text of the translation are evaluated in terms of form and translation.

Keywords: Zâtî, Bûsirî, Qasidat al-Burda, translation, poem 


\section{EXTENDED ABSTRACT}

In this article, a Turkish translation of the poem Qasidat al-Burda originally written in Arabic by Imam Bûsirî in the $7^{\text {th }}$ century is focused on. The Qasidat al-Burda written by Bûsirî in order to express his love and loyalty to the Prophet Mohammad has been accepted as one of the most beautiful examples of a eulogy in the field. This qasida having an important place in all Islamic societies was translated into many languages. Additionally, it deeply influenced the Turkish culture and literature and was translated and explained in verse or prose many times. A copy of the poem Qasidat al-Burda, examined in this article, was one of those translations. The translator of the work was a poet having the appellative 'Zâtî'. In Turkish literature, there were two authors who used that appellative. One of them was a classical Ottoman poet Zâtî who lived in the $16^{\text {th }}$ century, the other one was Zâtî from Keşan whose real name was Süleymân. However, it has not been established which of the peots this translation of Burda belonged to.

In the first part of the article, some information about Bûsirî and the Qasidat al-Burda will be given. The poet, Busiri, of 'Qasidat al-Burda' was famous and lived between the hijri years of 608 and 696/697. He lived and started his education in Delâs or Bûsîr, the countries of his parents. From the early years of his life he earned his living by working at goverment offices or performing his own work. Throughout his life, he worked in different positions including clerk, usher, calligrapher, governer, and lecturer. The first name he gave to his work was 'Qasidat al-Burda', 'Al-Kawākib ad-Durrīya fì Madh Khayr al-Barīya'. However, the poem was given several names by different people in time. The reason why the poet wrote Qasidat al-Burda and it became famous was related to a dream which was told more or less in the same way in the sources. Rumour has it that Imam Bûsirî was partially paralyzed. Then, not being able to do anything, the poet wrote a qasida in which he praised the Prophet Mohammad and requested a healing from God. That night, he saw the Prophet Mohammad in his dream. The Prophet asked Bûsirî to recite his qasida. After the poet finished reciting the qasida, the Prophet, with his blessed hands, anointed the paralyzed part of the poet's body and cover him with his (the Prophet's) cardigan. When the poet woke up, he realized that the paralyzed part of his body was healed. Also, Turkish explanations and translations of Qasidat al-Burda are presented in lists. In Turkish literature, 25 explanations and nearly 40 translations of the qasida were identified. The oldest translation copy belonged to Abdurrahîm Karahisarî.

In the second part, doubt about the author of the translation is examined along with information about the lives and works of both the authors are presented. One of the authors is Süleymân Zâtî. Born in hijri 1095 (gregorian 1684) in Gelibolu, Süleymân Zâtî is one of the Turkish sufi and divan poets that lived in $17^{\text {th }}$ century. The poet whose real name was Süleymân used the appellative 'Zâtî' in his poems. It is known that he had eight works, four of which were explanations. The other author is Zâtî from Balıkesir who was one the most important poets of $15^{\text {th }}$ century divan poetry. Zâtî was born in the Balıkesir town of Karesi province in 1471. Using pretty plain language, Zâtî was one of our most productive poets. Together with his most important work, dîvân, he has five works. 
In the third part, information about the copy, form, and translation of the work is presented. This translation, was between sheets 31b-44a in the journal numbered as 06 Yz. A 859/9 in the National Library. With a different meter from the source text, it was written as a 163 couplet. It is not possible to say the poet successfully applied the meter he chose for the text. The reason is that in several verses, prosody mistakes sourced from syllable omission or excess were detected. It was also detected that he occasionally changed the form of the words in order to rhyme or used the words as they were in the source text. In this part containing the evaluation of the translation, all the matters detected are explained by presenting examples.

In the last part, transcription of the translation is provided. The translation text is progressed together with the source text couplet by couplet. The couplets which have mistakes related to the meter are highlighted with footnotes. At the end of the study, the samples of exact copies of the translation are attached. 


\section{GIRIŞ}

Ünü, yazıldığı dili ve coğrafyayı aşan bazı manzumeler vardır. Kâ’b b. Züheyr (ö. 24/645 ?) ve İmam Bûsirî’nin (ö. 696-97/1297-98) farklı yüzyıllarda yazdıkları ve her ikisinin de Kasîde-i Bürde adıla meşhur olan şiirleri, bu manzumelere verilebilecek en güzel örneklerdendir. İlk Kasîde-i Bürde Kâ’b b. Züheyr'e aittir. Kâ’b önce Müslüman olduğunu işittiği kardeşi Büceyr (ö. 10/631'den sonra) ve Hz. Peygamber için bir hicviye yazmış, bu yergi sebebiyle ölüm cezasına çarptırılmıştır. Hz. Muhammed'in pişman olup huzuruna çıkanları bağışladığını öğrenince affedilmek umuduyla bir manzume yazar. Hz. Muhammed'in huzuruna yüzü örtülü bir şekilde çıkarak tövbe edip Müslüman olmak istediğini söyler. Bu sırada “Bânet Su' âd (Suâd ayrıldı)" diye başlayan kasîdesini de okur. Af talebini kabul eden ve kasîdeyi çok beğenen Hz. Muhammed, üzerinde bulunan hırkasını (bürde) Kâ’b b. Züheyr'e hediye eder. Bundan dolayı kasîde, "Kasîdetü'l-bürde" veya başlangıcı sebebiyle "Bânet Su 'âd” olarak adlandırılmıştır. (Ayçiçeği, 2015, s. 28-29; Demirayak, 2001, s. 566-567) İkinci "Kasîde-i Bürde” ise makalemizin konusunu teşkil eden ve İmam Bûsirî’ye ait olan manzumedir. Asıl değerini Hz. Muhammed'e duyulan sevgiden alan bu kasîdenin etrafinda zamanla farklı sanat dallarını da kapsayan yoğun bir kültür oluşmuştur. Çeşitli makamlarda bestelenmiş, medrese ve camilerde ders olarak okutulmuştur. Çok kereler hattatlar tarafından meşk, kattalar ve çiniciler elinde nakş edilmiştir. Aynı zamanda türlü hastalıklara şifa olduğu inancı, hastalara deva umudu vermiştir. Zira kasîdenin nâzımı da bu eseri vesilesiyle sıhhate kavuşmuştur. Dolayısıyla bu eser, yalnızca bir övgü şiiri olmaktan çıkmış; belirli adap kurallarına uyarak ve icazetle okunması gereken bir değer haline gelmiştir. Şairler ve nâsirler de böyle bir sevaba nail olabilmek gayesiyle birçok eser ortaya koymuşlar; şerhler, tercümeler, nazîreler yazmışlardır. Bu çalışmada; şerh ve tercüme geleneği içerisinde önemli bir yere sahip olan Kasîde-i Bürde’nin, Zâtî mahlaslı bir şair tarafından yapılan manzum tercümesi hakkında bilgi verilecektir.

\section{1. İmam Bûsirî ve Kasîde-i Bürdesi ${ }^{1}$}

Bûsirî adıyla meşhur olan "Kasîde-i Bürde" şairinin tam adı Muhammed b. Sa id b. Hammâd b. Muhsin b. Abdullâh b. Hayyân b. Sanhac b. Mellâl es-Senchâcî el-Bûsirî’ dir. Kaynaklar, şairin doğum tarihi olarak h. 608 (m. 1212) yılı Şevval ayının birine rastlayan salı gününü işaret ederler. Anne babasının memleketleri olan Delâs veya Bûsîr'de büyüdüğü ve tahsiline başladığı tahmin edilir. Bûsirî, küçük yaşlarından itibaren devlet dairelerinde çalışarak yahut kendi el sanatlarını icra ederek hayatını kazanmıştır. Hayatı boyunca kâtiplik, mübaşirlik, hattatlık, mutasarrıflık, küttab hocalığı gibi farklı görevlerde bulunmuş, bu vesileyle pek çok yer gezmiştir. Ölüm tarihi konusunda ise çok farklı rivayetler mevcuttur. Kesin olmamakla birlikte h. 696 yâhut 697 (m. 1297-1298) tarihi bilim adamlarınca en yakın tarih olarak kabul edilmektedir. Bûsirî’nin şiirleri dışında başka bir eserinin varlığı henüz bilinmemektedir. Kütüphanelerde dîvânının birkaç nüshası bulunmakla birlikle bu nüshalar bütün şiirlerini kapsamamaktadır.

1 Çalışmamızın bu bölümünde İmam Bûsirî ve Kasîde-i Bürde'si ile ilgili bilgiler aşağıdaki üç çalışmadan derlenmiştir: Kaya, 1992; Sezer, 1985; Şahin, 1997. 
Şairin Kasîde-i Bürde adıyla meşhur olan eserine verdiği ilk isim “el-Kevâkibü'd-dürriyye fî̀ medhi hayri'l-beriyye"dir. Ancak manzume zaman içerisinde farklı kişiler tarafından çeşitli şekillerde isimlendirilmiştir. Bunlardan bazıları; Bür'e, Bürdiyye, Büreyde, Mîmiyye, Kasîdetü'ş-Şedâid, Şifa Kasîdesi vb. olarak sıralanabilir. "Müs tef 'i lün / fâ 'i lün / müs tef 'i lün / fe "i lün” vezniyle yazılan ve 161 beyitten oluşan Kasîde-i Bürde, Bûsirî tarafindan belirli kısımlara ayrılmamıştır. Ancak eser üzerinde çalışanlarca genelde on bölüm olarak değerlendirilmiştir. Bu bölümlerden bazıları nefsin heva ve heveslerinin meni; Hz. Muhammed'in medhi, doğumu ve o esnada cereyan eden fevkalade hadiseler, Hz. Muhammed'in mi'raci ve sırlar1, "Cenâb-1 Hak celle ve alâ Hazretleri'nden mağfiret" ve "Hz. Muhammed canibinden şefaat talebi” şeklinde sıralanabilir.

Şairin Kasîde-i Bürde’yi yazmasının ve aynı zamanda kasîdenin bu derece meşhur olmasının sebebi kaynaklarda aşağı yukarı aynı şekilde anlatılan bir rüya hadisesine dayanır. Rivayete göre İmam Bûsirî, amansız bir felç hastalığına yakalanır. Bu halde elinden hiçbir şey gelmeyen şair, Hz. Muhammed'i medh ettiği bir kasîde yazarak Allah'tan şifa talebinde bulunur. O gece rüyasında Hz. Muhammed'i görür. Hz. Muhammed, Bûsirî’den kasîdesini okumasını ister. Şair, şiirini okuyup tamamladıktan sonra Hz. Muhammed onun vücudunun felçli kısmını elleriyle mesh eder, üzerine hırkasını örter. Şair uyandığında vücudunun sıhhate kavuştuğunu görür. Sabah evinden dışarı çıktığında sokakta bir dervişe rast gelir. Bu derviş kendisine; "Yâ Seyyidî! Efendimiz Hz. Muhammed'i medh ettiğin kasîdeyi bana verir misin ?” der. Daha önce de medihler yazmış olan şair, "Hangi kasîdemi istiyorsun, benim birçok medhiyyem vardır." deyince, mezkûr derviş; "Matla1 'E min tezekküri cîrânin bi-zî-Selemi' olan kasîdenizi istiyorum.” diye cevap verir. Bu şiiri daha önce hiçbir yerde okumayan, hiç kimseyle paylaşmayan şair, durum karşısında epeyce hayret eder. Şaşkınlığını dervişle de paylaşan şair, ona bu kasîdeyi hiç kimsenin bilmediğini söyleyerek onun nereden duyduğunu sorar. Derviş; "Dün gece Peygamber Efendimiz huzurunda okuduğun vakitte işittim." diye cevap verir. Bu konuşmadan sonra Bûsirî, kasîdesinin bir nüshasını dervişe verir. Böylece kasîde halk arasında meşhur olur. "Bürde", hırka olarak bildiğimiz bir üst giysisidir. Kasîdenin "Bürde" adını almasıyla ilgili öncelikli kanaat, bahsi geçen rivayette Hz. Muhammed'in Hırka-i Şerîf olarak bilinen giysisini şairin üzerine örtmesidir.

\subsection{Kasîde-i Bürde'nin Türkçe Şerh ve Tercümeleri ${ }^{2}$}

\subsection{1. Şerhler}

Kasîde-i Bürde'nin, Ebubekir Sıddık Şahin ve Sadık Yazar'ın konuyla ilgili tezlerinde tespit ve kayıt edilen Türkçe şerhlerinin sayısı 25 'tir. XVI. ve XX. yüzyıllar arasında yazılan bu şerhlerin büyük bir çoğunluğunun mensur olduğu ve yalnızca bir tanesinin şârihinin belirlenemediği görülür. Şahin, adı geçen çalışmasında bu şerhlerden ilkinin Le’âlî Ahmed b. Mustafa (ö. 1563)’ya ait olduğunu kaydeder. Le’âlî şerhinin diğer bir özelliği ise kütüphanelerde

2 Kasîde-i Bürde'nin Türkçe şerh ve tercümeleri ile ilgili bilgiler şu iki kaynaktan derlenmiştir: Şahin, 1997; Yazar, 2011. 
en fazla nüshası bulunan Türkçe şerh olmasıdır. Şeyhülislâm Mekkî Mehmed Efendi (ö. 1797)'nin Tevessül'ü ise bu şerhler arasında en mufassal olanıdır. Şerhler aşağıda liste olarak sıralanmıştır:

1. Ankaravî İbrâhim b. Süleymân b. Sâdık b. Mürsil el-Hanefî el-Ankaravî (ö. 1508'den sonra), Kasîde-i Bürde Şerhi.

2. Le’âlî, Ahmed b. Mustafa (ö. 1563), Şerh-i Kasîde-i Bürde. (Şahin, 1997, s. 154-210)

3. Şeyh Sa’dullâh el-Halvetî Müridî (ö. 1477), Şerh-i Kasîde-i Bürde. ${ }^{3}$

4. Mehmed Ma’rûf b. Mehmed Şerîf et-Trabzonî (ö. 1593), Şerh-i Kasîde-i Bürde.

5. Şeyhülislâm Bâlîzâde Mustafa b. Bâlî b. Süleymân Rûmî ? (ö. 1662), Şerh-i Kasîde-i Bürde.

6. Yahyâ b. Abdullâh (XVII. yüzyıl - I. Ahmed devri), Tercümetü'l-Esrâr fî Medhi Seyyidi'l-Ebrâr (Şerh-i Kasîde-i Bürde).

7. Mustafa b. Ahmed Bosnevî (XVII. yüzyıl - IV. Mehmed devri), Zübdetü'ş-Şürûhu'tTürkiyye.

8. Rızâ'î, Seyyid Hasan b. Abdurrahman Aksarayî (ö. 1669), Miftâhû's-Sa'âde (Manzum Kasîde-i Bürde Şerhi). (Cankurt, 2014)

9. Şeyh Abdullâh b. Şeyh Ahmed (ö. 1728), İrşâdiyye (Şerh-i Kasîde-i Bürde).

10. Şeyh Abdullâh b. Şeyh Ahmed (ö. 1728), Cübbe Şerh-i Kasîde-i Bürde.

11. Mekkî Mehmed Efendi İstanbulî (ö. 1797), Tevessül (Şerh-i Kasîde-i Bürde). (Ayçiçeği, 2020)

12. Mehmed b. Fazlullâh (ö. 1806'dan sonra), Şerh-i Kasîde-i Bürde.

13. Mehmed Emîn b. El-Emîr Feyzullâh b. Gül Ahmed er-Rûmî (ö. 1815), Şerh-i Kasîde-i Bürde.

14. Muhammed Fevzî b. Ahmed et-Tavasî (ö. 1900), Miftâhu'n-Necât. (Kuzubaş, 2007)

15. Prevezeli Âbidin Paşa b. Ahmed Dino (ö. 1906), Terceme ve Şerh-i Kasîde-i Bürde. (Harman, 2004)

16. Akhisarlı Hâfız İsmâîl Nazîf b. Muhammed Efendi (ö. ?), İ́klîdü’s-Sa’âde (Manzum Kasîde-i Bürde Şerhi).

3 Şeyh Sa'dullâh Halvetî’ye atfedilen bu şerh, onun isteği üzerine bir müridi tarafindan (1563 ile 1617 tarihleri arasındaki bir tarihte) yazılmıştır. Bkz. Yazar, 2011, s. 590-592. 
17. Kayacağî Süleymân Efendi (ö. ?), Şerh-i Kasîde-i Bürde.

18. Osmân Tevfîk (ö. ?), Şerh-i Kasîde-i Bürde Terceme-i Mücmeli.

19. Hasan Fehmî b. Mollâ Mustafa Efendi (ö. ?), Mecma'u’l-Fezâil.

20. Kastamonulu Hocazâde Mehmed b. Ali Senâî b. Ebîbekr b. Abdulbâkî (ö. ?), Kayıtlı Kasîde-i Bürde.

Kasîde-i Bürde bunlardan başka; Türkzâde Hacı Mehmed Ziyâüddîn (ö. ?), Rusçuklu Mehmed Hayrî (ö. ?), Rahmi Serin, Fevzi Aksoy ve Mehmet Balcı gibi isimler tarafından da şerh edilmiştir.

\subsubsection{Tercümeler}

XV. yüzyıldan başlayarak devamlı bir şekilde yazılan ve günümüze ulaşan Kasîde-i Bürde tercümeleri çoğunlukla manzum olarak kaleme alınmıştır. Kasîdenin tespit edilen en eski nüshası Abdurrahîm Karahisarî'ye aittir. Tespit edilen tercümeler aşağıda sıralanmıştır:

1. Abdurrahîm Karahisarî (ö. 1483'ten sonra), Tercüme-i Kasîde-i Bürde. (Ertaylan, 1960; Kahraman, 1997)

2. Kemâl Paşazâde, Şemseddîn Ahmed b. Süleymân b. Kemâl Paşa (ö. 1533), Tercüme-i Kasîde-i Bürde. (Günaydın, 1995; Saraç, 1994)

3. Zâtî (ö. ?), Tercüme-i Kasîde-i Bürde.

4. Ahmed Rıdvân (ö. 1528-1538 arası), Tercüme-i Kasîde-i Bürde. (Koç, 2018)

5. Müftüzâde (...) b. Halîl (ö. ?), Tercüme-i Kasîde-i Bürde.

6. Le’âlî, Ahmed b. Mustafa Saruhânî (ö. 1563), Tercüme-i Kasîde-i Bürde. (Kahraman, 1997)

7. Ebü’s-Senâ Ahmed Şemseddîn Sivasî (ö. 1597), Tercüme-i Kasîde-i Bürde. (Albayrak Sak, 2014)

8. Kemâlâtî Mehmed (1606'dan önce), Tercüme-i Kasîde-i Bürde.

9. Esâsî Efendi (1631'den evvel), Tercüme-i Kasîde-i Bürde.

10. Hüseynî, Seyyid Hüseyin b. Seyyid Alî el-Amasî (ö. 1650'dan sonra), Tercüme-i Kasîde-i Bürde.

11. Divitçizâde Mehmed Tâlib Üsküdarî (ö. 1679), Tercüme-i Kasîde-i Bürde.

12. Sükûtî, Mehmed b. Şeyh Mustafâ (ö. 1691), Tercüme-i Kasîde-i Bürde. 
13. Paşasaraylı Fazlî Efendi (ö. ?), Tercüme-i Kasîde-i Bürde.

14. Abdülhay Celvetî (ö. 1705), Tercüme-i Kasîde-i Bürde. (Ayçiçeği, 2016)

15. Nahîfî, Süleymân b. Abdurrahmân b. Sâlih el-İstanbulî- (ö. 1738), Tercüme-i Kasîde-i Bürde.

16. Abdullâh Efendi el-Hulvî (ö. 1746), Tercüme-i Kasîde-i Bürde.

17. Salâhî, Abdullâh Selâhaddîn-i Uşşâkî, (ö. 1782), Tercüme-i Kasîde-i Bürde.

18. Ahmed Arîfî (ö. 1781'den sonra), Tercüme-i Kasîdetü'l-Bürde.

19. İsmâîl Müfîd Efendi b. Ali el-İstanbulî (ö. 1803), Tercüme-i Kasîde-i Bürde.

20. Na'îmî (ö. ?), Tercüme-i Kasîde-i Bürde. (İlhan, 2017)

21. Nihâdî (ö. ?), Tercüme-i Kasîde-i Bürde.

22. Cihâdî (ö. ?), Tercüme-i Kasîde-i Bürde.

23. Sayrafî Mehmed (ö. ?), Tercüme-i Kasîde-i Bürde.

24. Alî b. İsmâîl Babadağî (ö. ?), Tercüme-i Kasîde-i Bürde.

25. Halepli Kudsîzâde Kadrî (ö. ?), Tercüme-i Kasîde-i Bürde.

26. Abdülhalîm Ken’ân (ö. 1950), Tercüme-i Kasîde-i Bürde.

27. Sûzî Ahmed Efendi (ö. ?), Tercüme-i Kasîde-i Bürde.

28. Abdurrahîm Üskübî (ö. ?), Tercüme-i Kasîde-i Bürde.

29. Hâfiz Mehmed Hayrî Efendi (ö. ?), Tercüme-i Kasîde-i Bürde.

30. Evrenyeli Abdürrahîm Efendi (ö. 1865), Tercüme-i Kasîde-i Bürde.

31. Diyarbakırlı Mehmed Said Paşa (ö. 1892), Tercüme-i Kasîde-i Bürde. (Ayçiçeği, 2015)

32. Konyalı Fahreddîn Efendi (ö. 1950), Tercüme-i Kasîde-i Bürde.

Kasîde-i Bürde, yukarıda zikredilen isimler dışında Sezai Karakoç, İlhan Armutçuoğlu (Armutçuoğlu, 2009) ve Mahmut Kaya tarafından da manzum olarak tercüme edilmiştir. Ayrıca eserin mütercimi belirsiz tercümeleri de bulunmaktadır.

\section{Tercüme-i Kasîde-i Bürde}

Üzerinde çalıştığımız bu Bürde tercümesi, Zâtî mahlaslı bir şaire aittir. Ancak tercümenin ünlü dîvân şairi Balıkesirli Zâtî’ye (ö. 1546) mi yoksa Keşanlı Süleymân Zâtî’ye (ö. 1738?) 
mi ait olduğu hakkında elimizde kesin bir bilgi yoktur. Tespit edilebilmiş tek bir nüshasının bulunması, eserin kime ait olduğu konusunda hüküm vermeyi zorlaştırmaktadır. Oldukça üretken ve birinci sınıf bir şair olan Balıkesirli Zâtî’nin, böylesine ünlü bir kasîdeyi tercüme etmek istemesi mümkündür. Ancak kaynaklarda şairin Arapça bildiği yahut böyle bir tercümesi olduğu hakkında kesin bir kayıt bulunmamaktadır. Tarafimızca ortaya konulacak olan metinde yer alan vezin problemleri de bize bu tercümenin Balıkesirli Zâtî’ye ait olmadığını düşündürmektedir. Konuyla ilgili elimizdeki diğer bir ipucu ise Kasîde-i Bürde'nin Halvetiyye tarikatı içinde önemli bir yere sahip olmasıdır. Keşanlı Süleymân Zâtî, bu tarikatın Celvetiyye koluna mensuptur. Dolayısıyla böyle bir tercüme kaleme almış olma ihtimali söz konusudur. Ebubekir Sıddık Şahin, konuyla ilgili yüksek lisans tezinde bu tercümenin hangi Zâtî’ye ait olduğunu tespit edemediğini belirtmekle birlikte Balıkesirli Zâtî’ye aitmiş gibi değerlendirmeyi tercih etmiştir. (Şahin, 1997, s. 110-111) Niyazi Ünver, Türk Dünyası Edebiyatçıları Sözlüğü’ne yazdığ1 "Zâtî" maddesinde, eseri Balıkesirli Zâtî'ye mâl etmiştir. (Ünver, 2007, s. 710-712) Orhan Kurtoğlu'nun Türk Edebiyatı İsimler Sözlüğ̈̈’ne yazdığg “Zâtî, Ivaz” başlıklı maddede ise, Zâtî̀ye mâl edilen bu eserin Süleymân Zâtî’ye ait olduğu ifade edilmektedir. (Kurtoğlu, 2013)

Tüm bu hususlar metinde bulunan vezin problemleriyle birlikte düşünüldüğünde, kasîdenin sahibinin Süleymân Zâtî olduğu fikri ağırlık kazanmaktadır.

\subsection{Süleymân Zâtî’nin Hayatı, Sanatı ve Eserleri ${ }^{4}$}

1095 (m. 1684) Gelibolu doğumlu Süleymân Zâtî, XVIII. asır Türk mutasavvıf ve dîvân şairlerindendir. Asıl adı Süleymân olan şairin, şiirlerinde Zâtî mahlasını kullandığı görülür. Şeyhi, Celvetiyye'nin Hakkıyye kolunun kurucusu İsmâil Hakkı Bursevî (ö. 1137/1725)'dir.

İsmâil Hakkı Bursevî’nin en önemli öğrencilerinden ve aynı zamanda halifesi olan Süleymân Zâtî, 1135 (m. 1722) yılı başlarında şeyhi tarafından irşad göreviyle Gelibolu’ya gönderilmiştir. Mürşidinin vefatından sonra faaliyetlerini Keşan'da sürdürmüştür. Şairin ayrıca "Keşânı̂” adıyla da nam bulması, hayatının sonuna kadar burada hizmet vermesi sebebiyledir.

Süleymân Zâtî öncelikle bir tekke şairidir. Bununla birlikte manzumelerinde dîvân şiirinin vezin ve nazım şekillerini kullandığ 1 ve eserlerinde Farsça şiirlere yer verdiği de görülür. Şairin lirik ve didaktik dokuya sahip şiirleri özellikle tekke muhitlerinde oldukça beğenilmiş, ilgiyle okunmuştur. Eserlerinde çoğunlukla Bursevî’nin kullandığı dile benzer bir üslup kullanması, hocasından aldığı eğitimden kaynaklanmakta ve mürşidinin kendisi üzerindeki tesirini ispat etmektedir. Aynı zamanda Niyâzî-i Mısrî (ö. 1105/1694)'den de etkilendiği görülür.

Kaynakların çoğu 1151 (m. 1738) yılında Keşan'da öldüğü konusunda birleşseler de bu husus ihtilaflıdır. Ali Senâî Efendi (ö. 1786)'nin, şeyhin vefatı üzerine yazdı̆̆ı bir tarih manzumesine dayanan Edirneli Ahmed Bâdî, 22 Cemâziyelevvel 1175 (m. 19 Aralık 1761) tarihini işaret eder. Yine Ali Senâî Efendi, bir şiirinde mürşidinin kabri üzerine bir türbe inşa

4 Süleymân Zâtî’nin hayatı, sanatı ve eserleri ile bilgiler şu iki kaynaktan derlenmiştir: Arslan, 2014; Şimşek, 2010; Şimşek, 2005. 
edildiğinden bahsetmektedir. Türbesi günümüzde mevcut olmayıp ya Balkan Savaşları sırasında ya da kendiliğinden yıkılmıştır.

Süleymân Zâtî’nin ölümünden sonra yerine oğlu ve halifesi Hüseyin Şâhî Efendi geçmiştir. Bilinen diğer halifeleri ise; Ali Senâî, Mustafa Efendi, Şarköylü Ahmed Fahreddin Efendi ve Seyyid Ebubekir Efendi'dir.

Zâtî, dördü şerh olmak üzere sekiz eser kaleme almıştır:

1. Dîvân: Zâtî’nin daha çok bir dîvânçe görünümünde olan dîvânı en önemli eserlerinden birisidir. Mürettep olmayan bu eser; 143 gazel, "Kasîde-i Hacc-ı Ma'neviyye” başlıklı otuz sekiz beyitlik bir kasîde ve "Târih-i Te 'lif" başlıklı iki beyitten oluşmaktadır. Dîvânın muhtelif kütüphanelerde yazma nüshaları bulunmaktadır. Eser, Mehmet Arslan tarafindan müellifin Sevânihu'n-nevâdir adlı eseri ile birlikte yayımlanmıştır. (Arslan, 1994)

2. Sevânihu'n-Nevâdir fî̀ Ma'rifeti'l-Anâsır: Mesnevi tarzında yazılan ve toplam 846 beyitten oluşan eserde; anâsır-1 erbaa, varlıkların zuhûru, âlem-i sagîr, âlem-i kebîr, nefsi tanıma, insan tabiatı ve akl-1 kül, akl-1 münebbih, akl-1 ma’âd, akl-1 ma’âş gibi hususlar yer almaktadır.

3. Miftâhu'l-Mesâil ve Misbâhu'l-Mahâil (20 Es'ile-i Mutasavvıfâneye Cevâb-nâmesi): Âhiret, levh-i mahfûz, mukadderât, hadîs-i kudsî, mebde ve meâd, insan ve cinlerin yaratılış sebebi, namazın sırları gibi konuları ihtiva eden eser, müellifin soru-cevap tarzında kaleme aldığı tasavvufî bir risaledir. Eser üzerine Asuman Omay tarafından yüksek lisans tezi hazırlanmıştır. (Omay, 2001)

4. Şerh-i Kasîde-i Ferîde li-İsmâil Hakkî: Eser, İsmâil Hakkı Bursevî'nin, "Bir 'elif' bul mekteb-i irfanda ol 'bâ'yı sor / Kad hamîde eyleyüp 'yâ' gibi ondan 'bâ'yı sor" matla'lı ve her beytinde bir sual bulunan on dokuz beyitlik manzumesinin şerhidir.

5. Şerh-i Muammâ-yı Nakşî Tercüme-i Hazret-i Zâtî: Şeyh Nakşî-i Akkirmânî’nin, "Nedir cânâ bil ol söz kim hadîs ü hem degil Kur'ân / Tekellüm itmemişdür çün perî anı ne hod insân" matla'lı dokuz beyitlik muammasının şerhidir.

6. Risâle fî̀ Mebde-i İnsân: Eserin tek nüshası İzmir Millî Kütüphane'de bulunmaktadır. Kaynaklarda zikredilmeyen ve te'lif sebebi belli olmayan eserde, insanın yaratılışı yanında mürşid-i kâmil, hakîkat-i Muhammediyye ve rûh konularına değinilmiştir.

\section{7. Şerh-i Kasîde-i Nûniyye.}

8. Şerh-i Kasîde-i Râ'iyye. 


\subsection{Balıkesirli Zâtî’nin Hayatı, Sanatı ve Eserleri ${ }^{5}$}

Zâtî, XVI. yüzyıl dîvân şiirinin en önemli şairlerindendir. 1471 yılında, Karesi vilayetine bağlı Balıkesir kasabasında doğmuştur. Kaynaklarda isminin Bahşî, Satı, Satılmış ya da İvaz olduğu yönünde değişik rivayetlere rastlanır. Ancak ebced hesabıyla şairin doğum tarihi 1471'i veren “İvaz” isminin doğru olduğu kabul görmüştür. Zâtî’nin çocukluk ve gençlik yıllarında nasıl bir eğitim gördüğü, neler okuduğu hakkında kaynaklarda yeterli bilgi bulunmamaktadır. Ailesi hakkında da fazla bilgi yoktur. Şairin, gençlik yıllarında geçimini çizmecilik mesleğiyle sağladığı ve aynı zamanda şiirler yazdığı bilinmektedir. Buradan hareketle şiir yazmaya erken yaşlarda başladığı söylenebilir. Kaynaklar onun tabiatını; neşeli, avare, serseri, taşkın ruhlu, rind ve kalender-meşreb olarak tasvir etmekte birleşmişlerdir. Zâtî’yi şairliğe sevkeden şey hiç şüphesiz yaratılışındaki şairlik cevheri ve coşkun mizacıdır.

Eserlerinden hareketle şairin; Manisa, Bursa, İznik ve Edirne'de bulunduğu bilgisine ulaşılmaktadır. Ancak bu şehirlerde hangi amaçla bulunduğu hususunda kaynaklarda yeterince bilgi verilmemiştir. Zâtî, tam tarihi bilinmemekle birlikte kırklı yaşlarında İstanbul'a gelmiştir. Kulaklarının ağır olduğunu kendisinden öğrendiğimiz Zâtî, burada hem bir şair olarak kendini ispat etmeye hem de geçimini bu yolla sağlamaya azmetmiştir. Sanatını geliştirmek için gerekli bilgileri edinmeye başlayan şair, aynı zamanda tahsilini ilerletmek amacıyla da şair meclislerinde bulunmaya, bir çevre edinmeye gayret etmiştir. Arapça gramer ve remilcilik kaidelerini öğrenmiştir.

Bu dönemde Hadım Ali Paşa (ö. 1511)'nın dîvân kâtibi Mesîhî (ö. 1513) ile tanışması Zâtî için bir dönüm noktası olur. Onun vesilesiyle Paşa'nın himayesine girer. Hadım Ali Paşa'nın hamiliği sayesinde hem birçok değerli âlimin bulunduğu sohbet ve meclislere katılma firsatı bulur; hem de padişahla tanışır. Zâtî, yine Paşa'nın tavsiyesi üzerine nevruz ve bayramlarda takdim ettiği kasîdelerle padişahın dikkatini çekmeyi başarır.

Zâtî, bazı dönemlerde himayesiz kalmış ve sıkıntılı zamanlar geçirmiştir. Kânûnî devrinde sunduğu kasîdelerle bir yıllığa bağlanmış olsa da İbrâhim Paşa'nın katliyle beraber geliri tamamen kesilmiştir. Şair, ömrünün kalan yıllarını ve yaşlılığını, Fâtih'de Sarıgüzel semtinde bulunan eviyle Bâyezîd Camii avlusunda bulunan dükkânı arasında geçirir. Bu dükkânda misk, anber, misvak gibi çeşitli şeyler sattığı; remilcilik, muskacılık ve mektupçuluk yaptığı, istek üzerine para karşılığında gazeller kaleme aldığı rivayet edilir. Bir süre sonra evi ile dükkânı arasındaki yolu dahi yürüyemeyecek duruma gelen şair, Koca İbrâhim Paşa Hamamı Çarşısı'nda başka bir dükkân tutmuş ve burayı şairlerin buluşma mekânı haline getirmiştir. Hayâlî Bey (ö. 964/1556-57), Yahyâ Bey (ö. 990/1582) gibi tanınmış isimlerin yanı sıra tanınmamış birçok şair de bu dükkâna uğramış; şiirlerini orada okuyup, tartışmışlardır. Hatta Bâkî (ö. 1008/1600)'nin de şairlik yolculuğuna bu dükkândan geçerek başladığı ve onun öğrencisi olduğu yönünde yaygın bir kanaat bulunmaktadır.

5 Zâtî'nin hayatı, sanatı ve eserleri ile ilgili bilgiler aşağıdaki üç çalışmadan derlenmiştir: Armutlu, 2018; Armutlu, 1998; Coşkun, 2013. 
Kaynaklarda yer alan bilgilere göre Zâtî, ömrünün son demlerini ağır hasta bir halde, yokluk ve sefalet içinde geçirmiştir. 953 senesi Ramazan'ının ikinci yarısında (m. Kasım 1546) vefat etmiştir. Dostları tarafından Edirnekapı Mezarlığı'na defnedilen şairin ölümüne tarihler düşürülmüştür.

Oldukça sade bir dil kullanan ve en üretken Osmanlı şairlerinin başında yer alan Zâtî'nin sanatına dair çeşitli değerlendirmeler yapılmıştır. Bu değerlendirmelerin eleştiri niteliğinde olanları; şiirlerini sanat kaygısı gütmeden yazdığı, dükkânına getirilen şiirlerden bazılarını kendine mâl ettiği, yazdığı şiir sayısının fazlalılığına bağlı olarak kendisini tekrar ettiği, şiirlerinde vezin problemlerine rastlandığı şeklinde sıralanabilir. Buna karşılık iyi bir eğitim almadığı halde kendi kendini yetiştirmiş olması, kulağındaki rahatsızlığa rağmen birinci sınıf şairler arasına girebilmesi, şiirlerinde yer alan el değmemiş mana ve hayaller, edebî sanatları ustalıkla kullanması ve dükkânında verdiği eğitim şairin takdire değer özelliklerindendir. Şiirlerinde mahallî kültürün ve gündelik hayatın izlerine, arkaik kelimelere, atasözleri ve deyimlere sıklıkla rastlanır. Özellikle gazelleri konu bakımından oldukça zengindir. Şiirlerine nazîreler yazılmış; kendisi de Hayâlî Bey, Melîhî (ö. 1481-1512 ?), Usûlî (ö. 945/1538-39) ve Tâcîzâde Câfer Çelebi (ö. 921/1515)'nin şiirlerine nazîreler yazmıştır.

Zâtî'nin Ahmed ü Mahmûd, Ferruhnâme, Siyer-i Nebî, Mevlit ve Fal-ı Kur'ân gibi eserlerinin bulunduğu rivayet edilse de aşağıda zikredilenlerden başkası elimizde bulunmamaktadır.

1. Dîvân: Zâtî’nin en önemli eseridir. Mürettep olan bu dîvân, şairin kendisi tarafindan tertip edilerek Şehzâde Mehmed'e sunulmuştur. Dîvânda bulunan gazel sayısı 1825'tir. Zâtî, dîvânında yer alan gazel sayısı bakımından -Muhibbî (ö. 974/1566)'den sonra- en çok gazel yazan ikinci şairdir. Gazeller dışındaki şiirlerini ise farklı nazım şekilleriyle yazılmış 248 manzume oluşturur. Dîvânda bulunan 1003 gazel, Ali Nihat Tarlan tarafindan 2 cilt halinde yayınlanmıştır. Birinci cilt "elif-zâ", ikinci cilt "zâ-nûn" arası harfleri kapsar. "Nûn" ile "yâ" harfleriyle yazılan 822 gazeli de Mehmet Çavuşoğlu ve M. Ali Tanyeri, 3. cilt olarak neşretmişlerdir. Eserin Türkiye kütüphanelerinde bulunan 10 nüshası bilinmektedir. (Ayrıntılı bilgi için bkz: Kurtoğlu, 2017; Tarlan, 1967; Tarlan, 1970; Çavuşoğlu ve Tanyeri, 1987)

2. Edirne Şehrengizi: Zâtî”nin "Sıfat-ı mahbubân-l şehr-i Edirne" başlığını taşıyan II. Bâyezîd zamanındaki Edirne güzellerini tasvir ettiği eseridir. Şair, şehrengizini mesnevi nazım şekliyle ve aruzun mefâ'îlün / mefâ'îlün / feûlün vezniyle kaleme almıştır. Biri Süleymaniye Kütüphanesi'nde olmak üzere toplamda dört nüshası tespit edilmiş olan eser 167 beyitten oluşmaktadır. Zâtî, Edirne Şehrengizi'nde Edirne'nin benzersiz güzelliği, kalesi, yeşilliği ve akarsuları hakkında kısa bir şehir tasviri yapmış ve Edirne'nin 52 güzelini tasvir etmiştir. Eser üzerine Derya Karaca'nın makalesi bulunmaktadır. (Karaca, 2018)

3. Şem ü Pervâne: Zâtî’nin dîvânından sonra tanınmış en ünlü eseridir. Eser, aruzun mefâ'îlün / mefâ'îlün / feûlün kalıbıyla yazılmıştır. 1534 yılında yazılan ve yaklaşık 4000 beyit olan mesnevinin dili sade ve üslubu akıcıdır. Konusu ise Şâh Jâle'nin oğlu Pervâne ile Çin Fağfûru'nun kızı Şem’ arasında geçen aşktır. Bilinen beş nüshasından biri Süleymaniye 
Kütüphanesi'nde olan eser üzerine Sadık Armutlu tarafından doktora tezi yapılmıştır. (Armutlu, 1998)

4. Letâyif: 16. asır sosyal hayatına dair önemli bilgiler barındıran ve bir hatırat niteliği taşıyan eser, iki kısımdan meydana gelmiştir. Tespit edilebilen iki nüshası bulunan birinci bölümde, Zâtî’nin devrin edebî ve tarihî şahsiyetleriyle diyalogları ve onlar hakkında yazdığı latifeler yer almaktadır. İkinci bölümde ise dönemin meslek ve sanat erbabı mizahi bir dille ele alınmıştır. Bu bölümün ise tek nüshası bulunmaktadır. Eserin her iki kısmı da makale olarak Mehmet Çavuşoğlu tarafından neşredilmiştir. (Çavuşoğlu, 1970; Çavuşoğlu, 1977)

5. Mektup: Eser, Gazâlî Deli Birâder namlı Mehmed adlı bir şahsın Mekke'den gönderdiği mizahi mektuba aynı üslupla verilen cevabından oluşmaktadır. Mektupta ise İstanbul'un, padişahın ve eş dostun ahvali sorulmaktadır. İki nüshası bulunan eseri Günay Kut neşretmiştir. (Kut, 1974)

\section{Zâtî ve Tercüme-i Kasîde-i Bürde'si}

\subsection{Nüshanın Tavsifi}

Milli Kütüphane 06 Yz. A 859/9 numaralı mecmuada 31b-44a varakları arasında bulunan nüsha, kaynak metinden farklı olarak 163 beyitten oluşmaktadır ve talik hatla yazılmıştır. Yer yer harekelerin kullanıldığı nüshada tercüme, kaynak metnin yer aldığı sayfaların derkenarına 13 satır olarak yazılmıştır. Kırmızı mürekkeple "Hâzâ Kitâbu Kasîde-i Bürde”" şeklinde başlık atılmıştır. Nüsha kütüphane kayıtlarına göre yaldız zencirekli, miklepli koyu kahverengi meşin ciltlidir. 175x110 - 100x52 mm. ölçülerinde sarı ince kağıda yazılmıştır.

\subsection{Tercümenin Şekil ve Çeviri Hususiyetleri}

Tek nüshasına ulaşılabilen bu tercüme, aruzun mefâ' 'îlün / mefâ '̂̀lün / mefâ 'îlün / mefâ 'îlün kalıbıyla kaynak metinden farklı bir vezinle yazılmıştır. Mütercimin kullandığı vezni eserine başarıyla uyguladığı söylenemez. Zira birçok mısrada hece eksikliği ya da fazlalığından kaynaklanan aruz kusurları görülmektedir. Birkaç örnek vermek gerekirse;

Biz[e] ol itmedi tekliff şol 'akl-l 'âciz olan şey

Tereddüd itmedük Kur'ân'uñ idrâkinde biz de anı (47. beyit)

şeklinde yazılan beytin ikinci mısraında hece fazlalığı bulunmaktadır. Misrada bir hece fazla olup beyitte yer alan "de" bağlacının kaldırılması sorunu gidermektedir.

Bular ashâb-ı file beñzedi yâhûd

Bir avuç hâk ile avlanan erbâb-ı tugyânı (70. beyit)

Yukarıdaki beytin ilk mısraında ise hece eksikliği tespit edilmiştir. Eksiklik tespit edilen beyitlerden bazıları tarafımızdan tamir edilmiştir. Örneğin aşağıdaki beyitte köşeli parantez içinde gösterilen [y1] hecesi hem beyti daha anlamlı hale getirmekte hem de eksik heceyi gidermektedir. 


\section{Havâs-ı mu 'cizi cem 'eyledüñ b̂̂-müşsterek anda Makâm-ı enbiyâ[yı] geçdüñ itdüñ anda seyrânı (114. beyit)}

Ayrıca metinde çok sayıda imale ve zihafa rastlanmaktadır. İmale, dîvân şiirinde sıklıkla kullanılan bir uygulamadır. Ancak zihaf çok ciddi bir aruz kusuru olarak görülmektedir. Çeviriyazılı metinde zihaflar italik olarak gösterilmiştir. Aşağıda tercümede tespit edilen zihaf örneklerinden bazıları yer almaktadır:

Benüm ey server-i 'âlem melâz u melce'im ol sen

Ki ya 'nî hâlet-i nez 'de hâlis itmekde îmânı (152. beyit)

İkinci mısrada yer alan “-hâ" hecesinin aruz gereği açık bir hece olması gerekmektedir.

Sabâ gülşende tahrîk eyledükçe 'azbe-i Bân'uñ

Her atrâb eyledükçe 'iys-i hâdî-i hoş-sühânı (161. beyit)

Yine beyitte ikinci mısrada yer alan "hoş" hecesi zihafa sebep olmaktadır.

Tercüme kaynak metinden farklı olarak "" kafiyesi yerine "ن" revî harfi "nûn" olan -1 redifi ve -ân mürdef kafiyesiyle kaleme alınmıştır. Mütercimin kafiyeyi gerçekleştirmek adına zaman zaman kelimeleri bozduğu ve bu sebeple beyitlerin anlamını koruyamadığı görülmektedir.

Zâtî, 161 beyit olan kaynak metni 163 beyit olarak tercüme etmiştir. Bu fazla beyitlerden bir tanesi, tercüme metninin 55 . beytidir ve kaynak eserde bir karşılığ 1 bulunmamaktadır:

Güneş gibi țlû' idüp hidâyet eyledi halkı

Dahı sầir ümem ihyâ olundı buldılar cânı

Diğerinin ise mahlas beyti (tercümenin son beyti) olduğu tespit edilmiştir:

Ola rûh-ı Resûlullâh'a sad gûne tahiyyetler

Ki Zâtî-i hakîüñ yokdur andan gayrı dermânı

Şairin lafızdan ziyade anlamı çevirmeye çalıştığı bu tercümede kaynak metindeki birçok kelimenin aynen alındı̆̆ı görülmektedir. Örneğin:

Hacerler ba'de tesbîh eyledi[ler] keff-i destinden

Misâl-i Yûnus-âsâ ez-haşâ-yı hût-ı bahrânı (71. beyit)

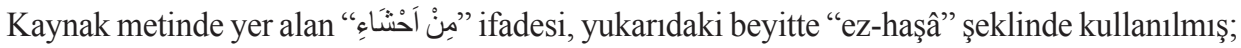
Arapça harf-i cerr olan "min” eki de, Farsça “ez” ekiyle değiştirilmiştir.

Yapışmazsa elümden rûz-ı mahşerde kerem idüp

Ve illâ deyesiz yâ zellete'l-akdâm 'isyânı (147. beyit)

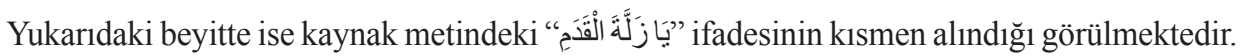
Tercümede çoğunlukla rastladığımız bu hususa; dördüncü beyitte “münketim”, altıncı beyitte 
"sekam", yedinci beyitte "anem", on beşinci beyitte "ketem", yirmi dokuzuncu beyitte "verem", kırk ikinci beyitte "munkasım", yetmiş altıncı beyitte "kasem", seksen beşinci beyitte "müttehem", yüz ellinci beyitte "mültezim" ve yüz elli birinci beyitte "ekem" şeklinde yer alan kelimeler örnek olarak verilebilir.

Kaynak metnin Arapça olmasından dolayı tercümede Arapça kelime sayısının fazla olduğu görülür. Buna rağmen tercüme genel olarak anlaşılır bir dille yazılmıştır. Arapça ve Farsça tamlamalara çok fazla rastlanmaz. Ancak mütercimin nadiren de olsa bazı beyitlerde anlamı vermekte zorlandığı görülmektedir. Bu hususa örnek olarak verilebilecek aşağıdaki beyitte, ikinci mısraın çevirisinin eksik olduğu tespit edilmiştir.

Çü mahbûb-ı Hüdā'sın [sen] şefā 'at ya Resūlallāh

Günahkâr ümmetüñ senden umarlar derde dermânı (36. beyit)

Beytin orijinali şu şekildedir:

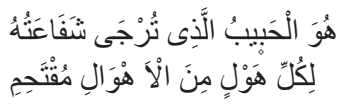

Bu sebeple tercümenin, 'OO, Hakk'ın habibidir, başa gelebilecek her türlü tehlike ve korkuya karşın şefaati umulan sevgilidir.” şeklinde örneklenebilecek bir mana içermesi gerekmektedir.

\section{SONUÇ}

İmam Bûsirî'nin Kasîde-i Bürde'sinin Zâtî mahlaslı bir şair tarafından manzum olarak yapılan Türkçe tercümesinin ele alındığı bu çalışmada; Türk şairler tarafından büyük rağbet gören bu kasîdenin, Türk edebiyatı dâhilinde kırk civarında tercümesinin bulunduğu tespit edilmiştir. Tercümenin müellifi hakkında elimizde bulunan verilerin Süleymân Zâtî’yi işaret ettiği yönündeki düşüncemiz ise bir tahminden öteye gitmemekte, tespit niteliği taşımamaktadır. Çalışmamızda ele alınan tercümenin çeviriyazılı metni bilinen tek nüshası üzerinden tarafımızca ortaya konmuştur. Bu metni incelediğimizde; Zâtî'nin tercümesinin kaynak metinden iki beyit fazla olduğu, bu beyitlerden birinin tercüme metninin içinde yer aldığı, diğerinin ise mahlas beyti olduğu görülmüştür. Şairin kullandığı vezni metne başarıyla uyguladığı söylenememektedir. Zira birçok mısrada hece eksikliği ya da fazlalığından kaynaklanan vezin problemlerine ve önemli bir aruz kusuru olan zihafa rastlanmaktadır. Zâtî’nin tercümesinde ele aldıği beyitlerin çoğunda anlamı bire bir yansıtmaya gayret ettiği ancak nadiren de olsa başarılı olamadığı görülmüştür. Kafiyeyi gerçekleştirmek adına zaman zaman kelimeleri bozduğu ve bu sebeple bazı beyitlerin anlamını koruyamadığı tespit edilmiştir. Sonuç olarak; Kasîde-i Bürde'nin Türk toplumu üzerinde kültür ve inanç dünyası bakımından büyük etkilere sahip olduğu bu tercüme üzerinden bir kez daha görülmüştür. ${ }^{6} \mathrm{Bu}$ büyük külliyatın yeni harflere çevriminin tamamlanmasıyla daha kapsamlı inceleme ve karşılaştırma çalışmalarının yapılmasına olanak sağlanması en büyük temennimizdir.

6 Konuyla ilgili bir Tübitak projesi bulunmaktadır. Bkz: Ayçiçeği, 2018. 


\section{Metin}

[31b]

\section{Hāẓā Kitābu Kaṣīdetü’l-Bürde}

Bismillāhirraḥmānirraḥīm

Mefā'ìlün / mefā'îlün / mefā'î̀ün / mefā'ìlün

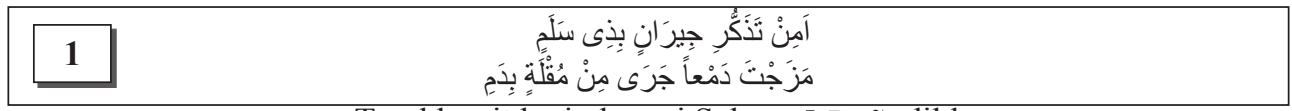

Teẓekkür itdüginden mi Selem cīrānıñı dilden

Bu çeşm-i terle halt itdüñ bebekden aḳıı ḳanı

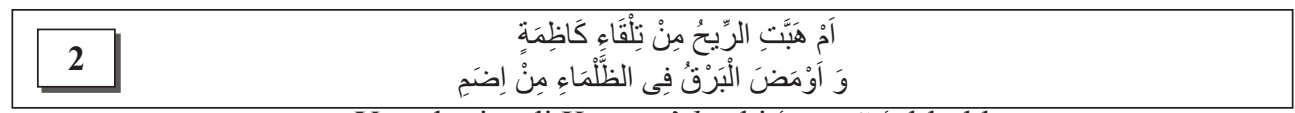

Ya yel mi esdi Kāẓıme'den ki 'aynuñ 'alīl oldı

Yahūd z̧almā-ı leylden şu 'leler mi urdı rahşāanı

\begin{tabular}{|c|c|}
\hline 3 & 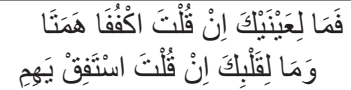 \\
\hline
\end{tabular}

Ne oldı çeşmüñe giryān oluban sākin olmazlar

'Aceb ḳalbüñ ifāḳat bulmadı eyler bu efḡānı

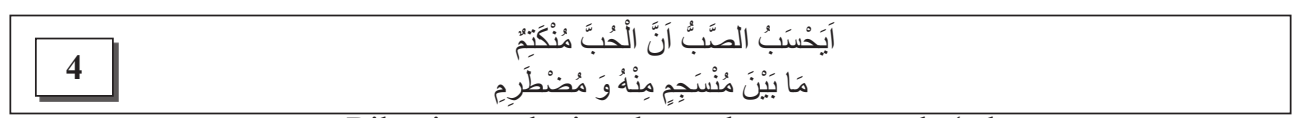

Bilürsin münketim olmaz aḳıc1 göz yaşıyla '1şk

Yanucı ḳalp arasında var iken böyle hicrānı

[32a]

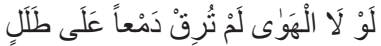

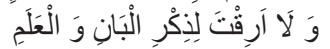

Eger kim '1şḳuñ olmazsa țalel üstine dolmazduñ

Gözüñ yaşın daḩı yād eylemezdüñ ḳāmet-i bānı

\begin{tabular}{|c|c|}
\hline 6 & 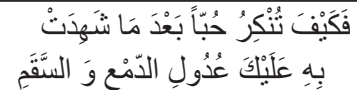 \\
\hline
\end{tabular}

N[iy]e inkār idersüñ hāāet-i '1şḳ1 ki şāhiddür

Seḳamla çeşm-i nem oldı anuñ 'adliyle bürhānı

71

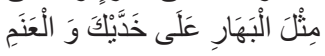

Yanaġında anuñ işbāt olmuşken gül-i aḥmer

Daḥı eşk-i revānından 'anem gibi aḳan ḳanı 


\begin{tabular}{|c|c|}
\hline 8 & 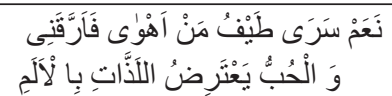 \\
\hline
\end{tabular}

Çü geldi dīde-i hāane hayāli uyḳusuz ḳaldım

Mübeddel itdi leẓz̄ātı anuñ cümle-i ạ̣zānı

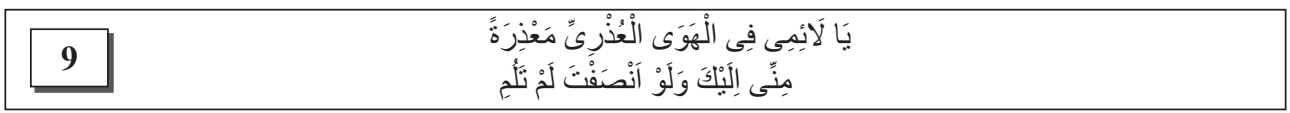

Benüm ‘özrüm ḳabūl eyle melāmet itme ey lā' im

Eger derdüm bilüp inșāf iderdüñ terk idüp anı

\begin{tabular}{|c|c|}
\hline 10 & 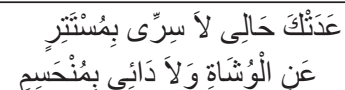 \\
\hline
\end{tabular}

Şu dermānsız olan derde giriftār oldum ammā kim

Ki ḳādir olmadum iḩfāya ol ḥāl-i perīşānı

\begin{tabular}{|c|c|}
\hline 11 & 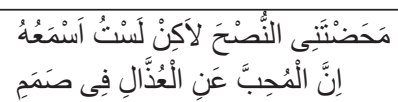 \\
\hline
\end{tabular}

Nașị̣at eyledüñse gerçi baña lỉkin ey nāṣị̣

Çü 'āşı̣̂lar işitmezler melāmetden ḳo señ anı

[32b]

\begin{tabular}{|c|c|}
\hline 12 & 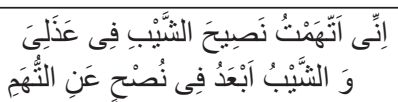 \\
\hline
\end{tabular}

Çü şeybüm baña nuṣh itdi ben anı eyledüm töhmet

Nedür vechi kişi şeybe ḳıla bendile bühtānı

\begin{tabular}{|c|c|}
\hline 13 & 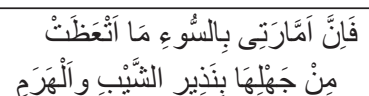 \\
\hline
\end{tabular}

Benüm emmāre nefsüm pend-i pīi dutmadı hergiz

Ki bu deñlü nașịhatler iderken şeyb-i nurānī

\begin{tabular}{|c|c|}
\hline 14 & 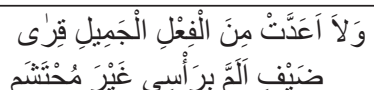 \\
\hline
\end{tabular}

Bir a māl-i pesendīde görüp ben itmedüm ḥāżır

Ne ikrām eyledüm başumdaki ḍayf-ı sefìdānı

$$
\begin{aligned}
& \text { لَوْ كُنْتُ اَعْلَمُ آَنِّى مَا أُوَقِّرُهُ }
\end{aligned}
$$

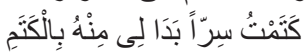

Ri'āyetde ḳuṣūrum bilse idüm pīr-i mihmānıñ

Ketemle ketm iderdüm ol 'alāmāt-1 sefìdānı 


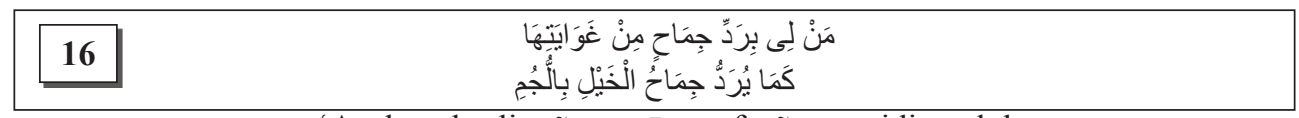

'Aceb serkeşligüñ emmāre nefsüñ nerm idinmekdür

Şu esb-āsā licāmıyla ki fāris żabṭ ider anı

\begin{tabular}{|c|c|}
\hline 17 & 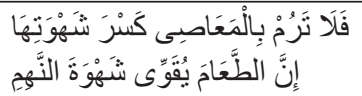 \\
\hline
\end{tabular}

Șaḳın 'ișyān ile kesr itme sen bu şehvet-i nefsi

Aña bu vechile iṭ ām iderseñ arturur anı

[33a]

\begin{tabular}{|c|c|}
\hline 18 & 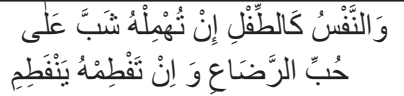 \\
\hline
\end{tabular}

Bu nefs şol țıfla beñzer kim rıḍā' a meyl ider ammā

Eger vaḳtiyle südden kesdürürsen unıdur anı

\begin{tabular}{|c|c|}
\hline 19 & 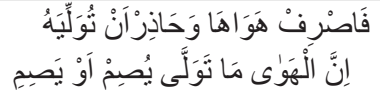 \\
\hline
\end{tabular}

Ki sen bu nefsi ḥākim ḳılma özüne bilürsin kim

Saña vālī olursa arturur sehvile nisyānı

\begin{tabular}{|c|c|}
\hline 20 & 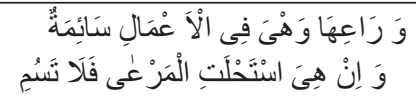 \\
\hline
\end{tabular}

Murā' āt-1 riyāżetde yürüt sen nāḳa-i '1şḳ̂

Çerā-gāh-1 leẓā' iẓde aña itdürme cevlānı

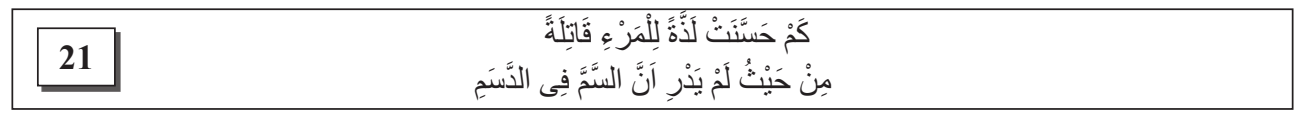

[Daḩ1] leẓzet yönünden ḩoş gelür emmāre-i nefse

Velỉkin semm-i ıżrar-1 ricāle hadd ü pāyānı

$$
\begin{aligned}
& \text { وَاخْشَ الأَََّائسنَ مِنْ جُوعِوَ مِنْ شَبْعِ }
\end{aligned}
$$

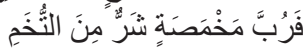

Șaḳın cū' u şiba dan ikisinde hazer eyle ${ }^{7}$

Ki olur nice cū 'uñ artucaḳ sehvile noḳșānı

\begin{tabular}{|c|c|}
\hline 23 & 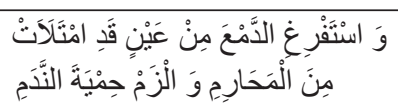 \\
\hline
\end{tabular}

Şu gözlerden aḳan ḥarām[1l]a var [sen] dile şimdi

Anuñ sen tevbe-i '1şḳıla gel olĝ̣l peşīmānı

$7 \quad$ Misra vezne uymamaktadir. 


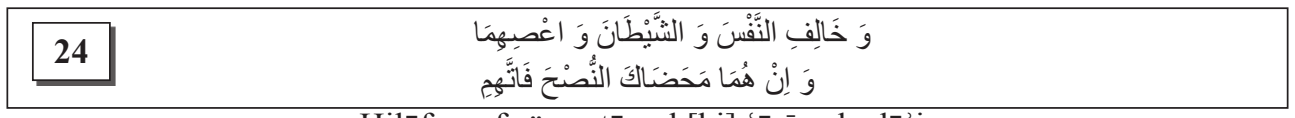

Huilāf-1 nefs ü şeyțān ol [ki] 'āṣī eyle dā'imen

Eger maḥż-1 nașị̣atde olursa töhmet it anı

[33b]

\begin{tabular}{|c|c|}
\hline 25 & 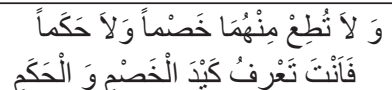 \\
\hline
\end{tabular}

Huuṣūmetde hüukūmetde sen uyma nefs ü şeyțāna

Bilürsin bunları fi 'li degildür emr-i Rabbānī

\begin{tabular}{|c|c|}
\hline 26 & 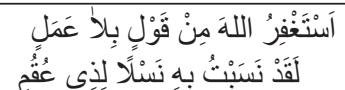 \\
\hline
\end{tabular}

Kelām-1 bī- 'amelden çünki itdüm Haḳḳ’a istig̀fār

Dahı beñzetdüm ol og̉lan dog̉urmaz 'avrata anı

27

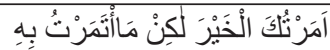

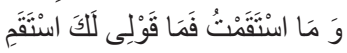

Saña emr eyledüm hayrı velī ben dutmadum emri

Pes ol ḳavlüñ nedür așșısı didüm dutmadum anı

\begin{tabular}{|c|c|}
\hline 28 & 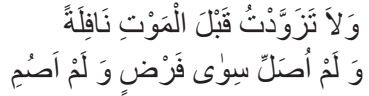 \\
\hline
\end{tabular}

Ölümden öñ nevāfilden azık idünmedüm nesne

Şu farżdan ġayrı anuñ da çıḳısar bunca noḳșānı

29

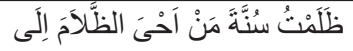

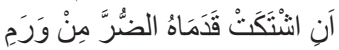

'Aceb kendüme zulm itdüm ki ị̣yā itmedüm leyli

\begin{tabular}{|c|c|}
\hline 30 & 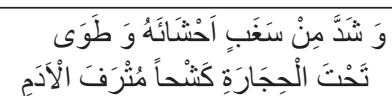 \\
\hline
\end{tabular}

Veremden şākīi iken ol resūlüñ pāy-1 rahş̧ānı

Daḩı muḥkem idüp beste ḩaşā-yı cenbi cū'dan

Ki bir iki ḥacerle tutar idi cāy-ı zādānı

[34a]

31

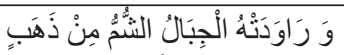

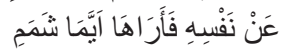

Ulu țag̉lar aña zer olmag̉içün iltimās itdi

Velì meyl itmeyüp i'rāż itdi rūy-1 mecīdānı ${ }^{8}$

8 Misrada vezin bozulmaktadır. 


\begin{tabular}{|c|c|}
\hline 32 & 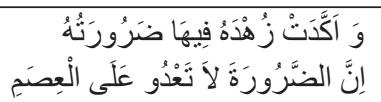 \\
\hline
\end{tabular}

Anuñ zühdiñ mü' ekked ḳıldı faḳr u iḥtiyācı hem

Anuñla faḩr iderdi artar idi rif' at-i şānı

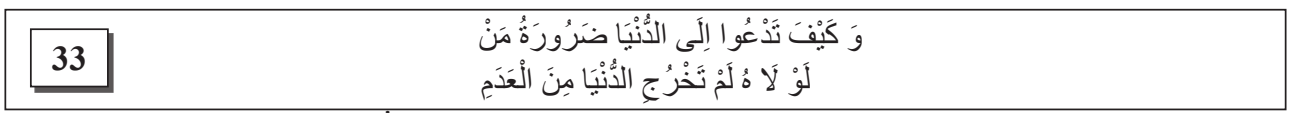

Żarūret nite da'vet ide anı meyl-i dünyāya

Cihāna gelmese ol dutmaz idi kevn ü mekānı

\begin{tabular}{|c|c|}
\hline 34 & 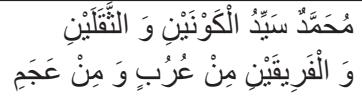 \\
\hline
\end{tabular}

Muhammed seyyidü'l-kevneyn hatemü'l-mürselin old1

Anuñçün ins ü cinne șādır oldı hükkm-i fermānı

35

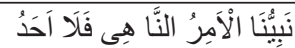

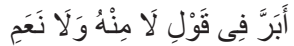

Anuñ mișli ehad yoḳdur ki ḳıla emr-i bi'l-ma 'rūf

Dahıı nehy-i 'ani'l-münkerde yoḳdur anuñ [a]krānı

\begin{tabular}{|c|c|}
\hline 36 & \\
\hline
\end{tabular}

Çü maḥbūb-1 Hüdā’sın [sen] şefā at ya Resūlallāh

Günahkār ümmetüñ senden umarlar derde dermānı

\begin{tabular}{|c|c|}
\hline 37 & 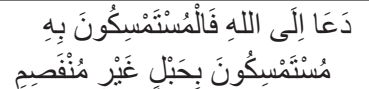 \\
\hline
\end{tabular}

Çü itdi raḥmet-i Raḥmān'a da 'vet ittibā' eyle

Yapış ol hạabl-i şer'a münḳațı' olma[ya] rīsmānı

[34b]

38

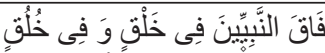

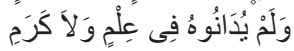

Dahhı fă'iḳdür ol hulkịiyle hilḳatde nebiyyīne

Müşābih olmadı 'ilm ü 'amelde aña bir vānī

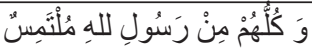

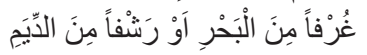

Resūl'üñ bahrr-i 'ilminde devāya mültemislerdür

Ya bir gurf yem-i hịkmetde ya bir reșf 'ilm-i reyyānı 


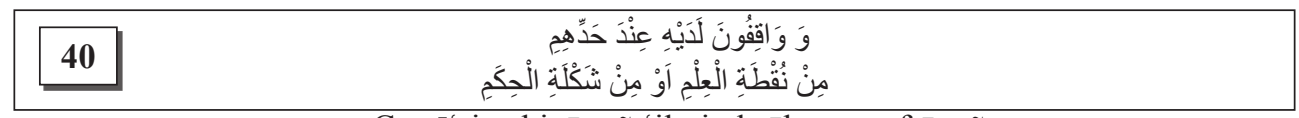

Cemī' -i enbiyānuñ 'ilmi ol şāh-1 ser-efrāzuñ

Katında noḳțadur zỉrā ki oldur 'ilmüñ 'irfānı

\begin{tabular}{|c|c|}
\hline 41 & 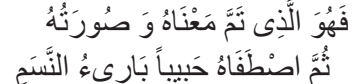 \\
\hline
\end{tabular}

Halāyıḳdan [anuñ] çün șūret ü ma nāsı efḍaldür

Anuñçün kendüye maḥbūb idindi anı Yezdān'1

\begin{tabular}{|c|c|}
\hline 42 & 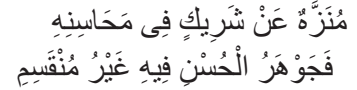 \\
\hline
\end{tabular}

O şāh-1 enbiyāya hüsn [ü] şevketde naz̧īr olmaz

Ki zīrā cevher-i hüsni degildür munḳasımānı

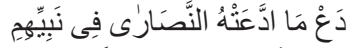

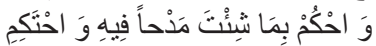

O ḳavl-i bāṭlından müşrikīnüñ iḥtirāz eyle

Kirāmu'n-nās ḥaḳkı̣ıda ne efụal ise it anı

[35a]

\begin{tabular}{|c|c|}
\hline 44 & 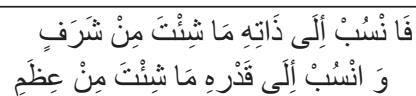 \\
\hline
\end{tabular}

Şerefden ḳādir oldığun ḳadar nisbetle yād eyle

'İżamdan cümle meddāḥuñ sen olġıl hem-sühnandānı

\begin{tabular}{|c|c|}
\hline 45 & 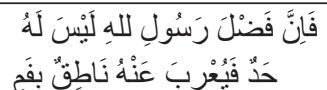 \\
\hline
\end{tabular}

Resūl'üñ fażlına ḥadd ü nihāyet yoḳ ki bir ‘āḳıl

Anı fehm idebile yoḳ ki ide ol beyān anı

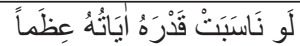

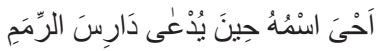

Egerçi fażlı ḳadrince ideydi mu cizāt iẓhār

Añılduḳda anuñ adı dirildürdi remīmānı

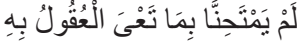

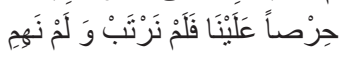

Biz[e] ol itmedi tekliff şol 'aḳl-i ‘āciz olan şey

Tereddüd itmedük Kurān'uñ idrākinde biz < de > anı 


\begin{tabular}{|c|c|}
\hline 48 & 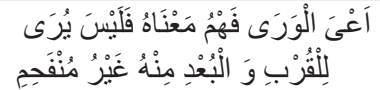 \\
\hline
\end{tabular}

Çü 'aḳl u fehm anuñ idrākine ‘āciz ü ḳāṣırdur

Nice taḳdīr ide ḳurbuñ u bu duñ bir sühandānī

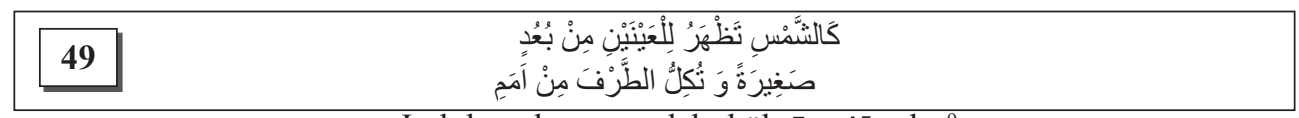

Iraḳdan olsa şems daḩı kübrā saḡīr olur ${ }^{9}$

Veli gözler ḳamaşa yaḳından itse lem 'ānı ${ }^{10}$

\begin{tabular}{|c|c|}
\hline 50 & 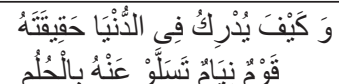 \\
\hline
\end{tabular}

Nite idrāk ide fażl u kemālātın bu dünyāda

Kanā at eyleyenler düşde görmekle o Sulțān'1

[35b]

\begin{tabular}{|c|c|}
\hline 51 & 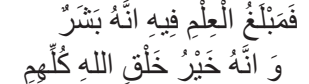 \\
\hline
\end{tabular}

Bu deñlü halḳ-1 ‘̄àlem bildi ancaḳ ol beşerdür kim

Ki maḩlūḳātuñ olur efụali vü muḥteşimānı

\begin{tabular}{|c|c|}
\hline 52 & 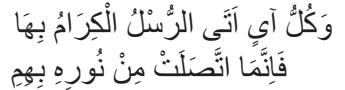 \\
\hline
\end{tabular}

Her āyet kim getürdiler nebīler ḳavmine cümle

Anuñ nūrından alup yaḳdılar şem 'ü fürūzānı

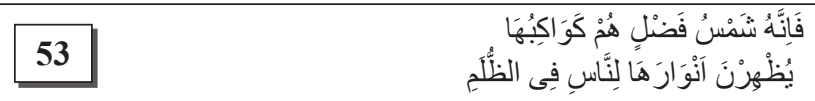

O bir huūrşīd-i fażluñ kevkebidür enbiyā vü rusl

Yaḳarlar nās içün zulmāda ol şem '-i şebistānı

Ne halḳ olur ki virmiş aña hü̈sni dürrini ol ${ }^{11}$

Cemāl ü hüsn ü ikrām ile tezyīn eyleyüp anı

Güneş gibi țulū' idüp hidāyet eyledi halḳı

Daḩı sā' ir ümem ihyāa olundı buldılar cānı ${ }^{12}$

9 Misra vezne uymamaktadir.

10 Misra vezne uymamaktadir.

11 Misra vezne uymamaktadir.

12 Bu beytin kaynak metinde karşılığı yoktur. 


\begin{tabular}{|c|c|}
\hline 55 & 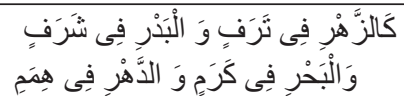 \\
\hline
\end{tabular}

Terefde ol çiçek gibi şerefde mișl-i bedr old1

Keremde baḥr-āsādur himemde țūl-i ezmānī

[36a]

56

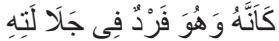

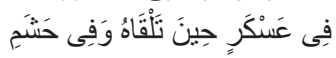

Ki gūyā ferd iken anı meḥābetle celāletden

Șanurdıñ leşker içinde yürür yoḳ ḥadd-i pāyānı

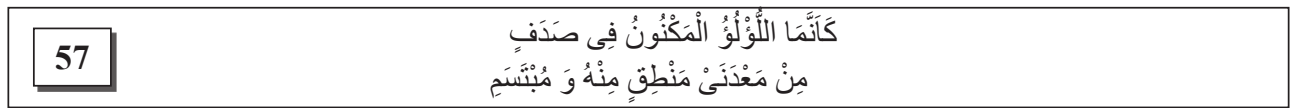

Eger kim ḥuḳka-i cevher-feşān olsaydı ețrāfa

Mübārek dişleri lü’ lü gibi iderdi lem 'anı

\begin{tabular}{|c|c|}
\hline 58 & 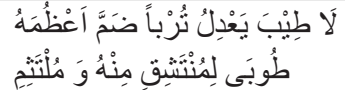 \\
\hline
\end{tabular}

Mübārek merḳad-i hāaki gibi bir țıbb-1 pāk olmaz

Sa āadet ol kişinün kim ḳoçup būs eyleye anı

\begin{tabular}{|c|c|}
\hline 59 & 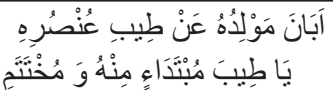 \\
\hline
\end{tabular}

Naẓar eyleñ Resūl'üñ bed' ü ḩatmine ki ol şāhuñ

Ne gökçek ibtidāsı var ne a lā intihāyānı

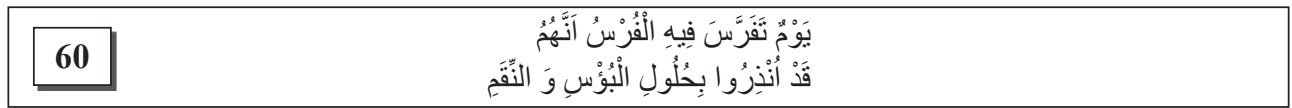

Ferāsetle o gün kim ḳavm-i Fāris dog̉duġın bildi

Katı ḩavf eyleyüp çekdiler andan renc ü niḳmānı

\begin{tabular}{|c|c|}
\hline 61 & 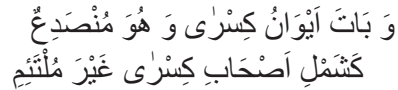 \\
\hline
\end{tabular}

Yarıldı țāḳ-1 Kisrā heybetinden yevm-i mevlūduñ

O havfile perākende olup enșār u a vānı

62

$$
\begin{aligned}
& \text { وَ النَّارُ خَامِدَةُ الَْا نْفَسَ مِنْ اَسَفِ }
\end{aligned}
$$

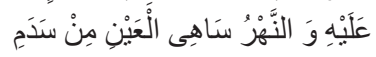

Daḩı āteş-perestiñ söndi odı farṭ-1 hüznünden

Nedāmetden ṣog̉uldı ḳurıyup ol cūy-1 ceryānı 
[36b]

63

$$
\begin{aligned}
& \text { وَسَاءَ سَاوَة اَنْ غَاضَتَتْ بُحَيْرَتُهُهَا }
\end{aligned}
$$

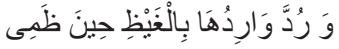

Yire geçdikde Sāve baḥri ehli oldılar ḥayrān

Gerüye 'avdet itdiler ġażabla cümle 'aţ̧̦ānı

$$
\begin{aligned}
& \text { كَأَنَّ بِالنَّارِ مَا بِالْمَاءِ مِنْ بَلَّلِ }
\end{aligned}
$$

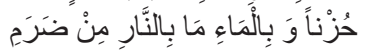

Ruṭūbetden eserer var idi gūyā nār-1 Kisrā'da

Harāretden țutuşup Sāve'nüñ ol baḥr-1 'ummānı

65

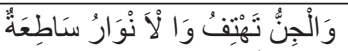

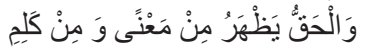

\begin{tabular}{|c|c|}
\hline 66 & 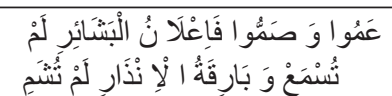 \\
\hline
\end{tabular}

Çü çün hātifden ol envār-1 sāṭı'dan nidā itdi

Ki ḥaḳḳa zạahir [ü] bāṭın bu gice buldı bürhānı

\begin{tabular}{|c|c|}
\hline 67 & 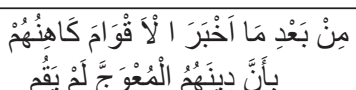 \\
\hline
\end{tabular}

Bu ḳavm a'mā eșamm olup işitmedi bu tebşīiri

Daḩı görmediler ol berḳ-endāz-ı kemākānı

\begin{tabular}{|c|c|}
\hline 68 & 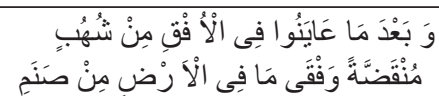 \\
\hline
\end{tabular}

Hुaber virdiklerinden ṣoñra ḳavmine bu kāhinler

Ki şimden gerü olmaz eger edyānuñ șebātānı

Dahı çün gördiler gökden şihābı yire döküldi

Șanemler bile olmuş gördiler hep ser-nigūnānı

[37a]

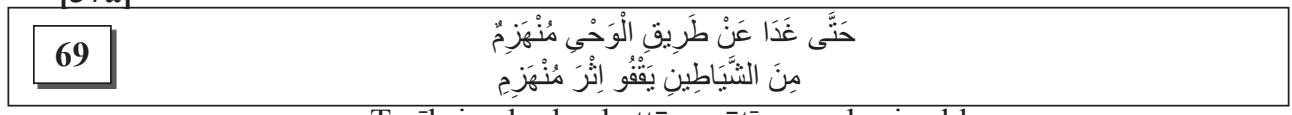

\begin{tabular}{|c|c|}
\hline 70 & 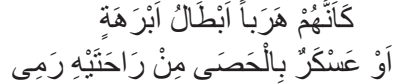 \\
\hline
\end{tabular}

Ṭariḳ-i vaḥyden ḥattā şeyāțīn munkesir oldı

Biri birinüñ ardınca ḳaçardı cümle şeytānı

Bular așhāb-1 fĩle beñzedi yāhūūd ${ }^{13}$

Bir avuç hāk ile avlanan erbāb-ı țug̉yānı

13 Misrada hece eksikliği sebebiyle vezin bozulmaktadır. 


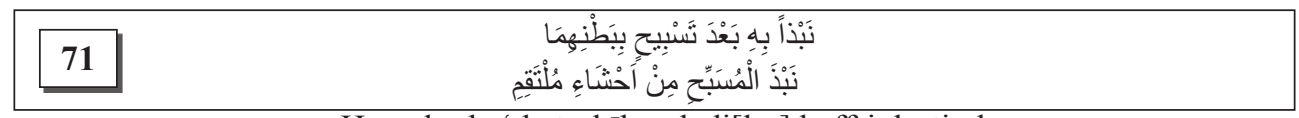

Hacerler ba de tesbīh eyledi[ler] keff-i destinden

Misāâl-i Yūnus-āsā ez-ḥaşā-yı ḥūt-ı baḥrānı

\begin{tabular}{|c|c|}
\hline 72 & 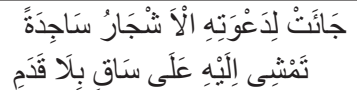 \\
\hline
\end{tabular}

İcābet eyledi eşcār gelüben itdiler secde

Şehādet idüben sensin resūl-i āḩir zemānı

\begin{tabular}{|c|c|}
\hline 73 & 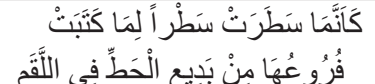 \\
\hline
\end{tabular}

Gelürken yollar üzere g $\bar{u} y \bar{a}$ kim yazu yazmışlar

Furū iyle kitābet eyleyüp hatṭ-1 garāibānı

\begin{tabular}{|c|c|}
\hline 74 & 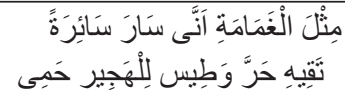 \\
\hline
\end{tabular}

Seḥāb-āsā aña sāye olur[lar]dı harāretden

Sa ādetle ne yire çıkssa gitse ol kerem-kānı

\begin{tabular}{|c|c|}
\hline 75 & 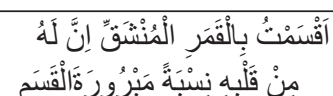 \\
\hline
\end{tabular}

Kasem idem ben ol şaḳku'l-ḳamerle intisābı var

Resūl'üñ ḳalbine vardur o bedrüñ intisābānı

[37b]

\begin{tabular}{|c|c|}
\hline 76 & 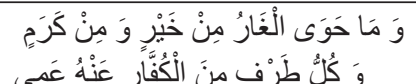 \\
\hline
\end{tabular}

Muhịit-i gāar olan hayr [u] keremde saña and içem

Ki küffār-1 ḍalālet-kāruñ a mā oldı 'aynānı

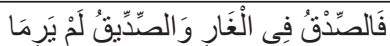

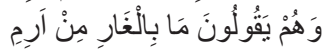

Pes ol gāār[ın] içinde ḥıfẓ idüp Șıdḳ[ile] Șıddịk’ı

Bu gāāra ug̣ramamış didiler efrād-ı insānī

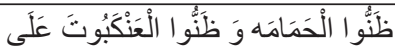

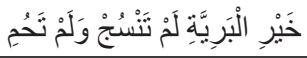

Hamām [u] 'ankebūtuñ devrini inkār ider bunlar

Gümān itdiler aḥbār-1 beriyye ura devrānı 


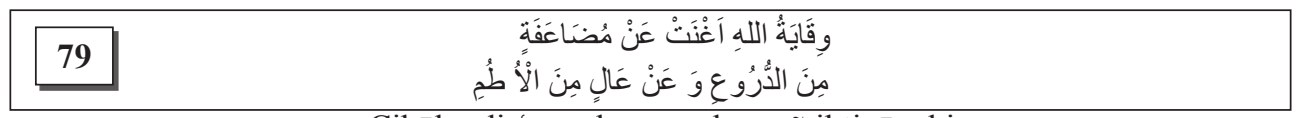

Cibāl ü dir'a vü ḥıṣna yoḳ anuñ ị̣tiyācı kim

Çü beyt-i 'ankebūt ile Hüudā ḥıf̣ eyledi anı

\begin{tabular}{|c|c|}
\hline 80 & 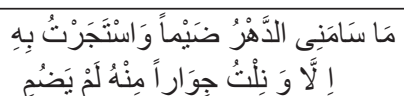 \\
\hline
\end{tabular}

Bu dehr-i bì-vefānuñ zulm ü cevrinden sıġındım ben

Anuñ şer ine vü ḳavline buldum derde dermānı

\begin{tabular}{|c|c|}
\hline 81 & 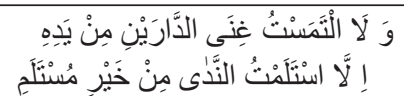 \\
\hline
\end{tabular}

Daḩı iki cihānuñ ben ġınāsın istememişken

Baña virdi kef-i cūdından artık ḳıldı ihsānı

[38a]

\begin{tabular}{|c|c|}
\hline 82 & 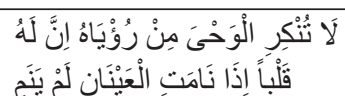 \\
\hline
\end{tabular}

Șaḳın rüyā ile vaḥyini inkār eyleme zīrā

Mübārek gözlerin yumsa uyumaz ḳalb-i yaḳżānı

\begin{tabular}{|c|c|}
\hline 83 & 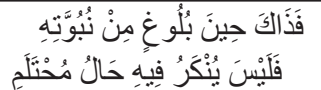 \\
\hline
\end{tabular}

Resūl'üñ düşdeki vahyyine inkār eylemez zīrā

Uyumazdı mübārek ḳalbi nā'im olsa 'aynānı

\begin{tabular}{|c|c|}
\hline 84 & 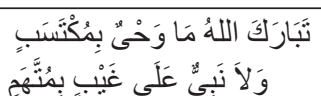 \\
\hline
\end{tabular}

Yüce Allāh'uñ ol vahyi degildür iktisābile

Nebīler müttehem olmaz haber virmekde gaybānı

85

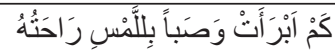

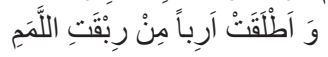

Şifā buldı nice derd ehli mesḥ-i dest-i luṭundan

Halāṣ itdi cehāletden nice merd-i garībānı

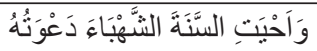

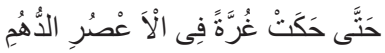

$O l$ hayāl eyledi ki sāl-i şehbā'ı du āsıyla

Şol iki cephesinde gurreye beñzetdiler anı 


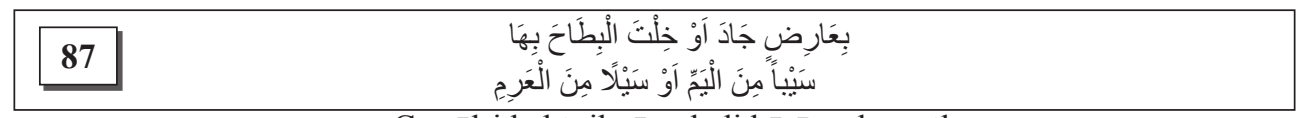

Çü sāl-i ḳaḥṭ̂ iḥyā eyledi bārān-1 keșretle

Șanaydıñ vādī-i baṭ̣̂āyı țutdı seyl-i 'ummānı

\begin{tabular}{|c|c|}
\hline 88 & 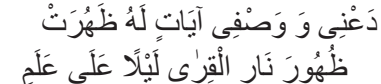 \\
\hline
\end{tabular}

Ko biz zikr idelüm şol mu cizātı z̧āhir olmışdur

Ki pür-nūr șalmış ol nūr-1 dürri gibi mīzān[1] ${ }^{14}$

[38b]

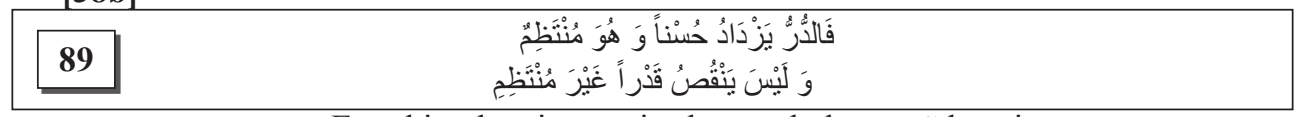

Eger kim dürr-i naẓm itsek mezīd olur anuñ ḥüsni

Dahı̆ naẓm itmesek ḳadrine virmez naḳṣ-1 nokṣānı

\begin{tabular}{|c|c|}
\hline 90 & 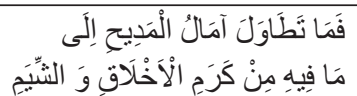 \\
\hline
\end{tabular}

Yetişmez 'aḳlı vașșāfuñ kim ahlāḳ-1 kerīmine

Egerçi nice yıllar durmayup medh eylese anı

\begin{tabular}{|c|c|}
\hline 91 & 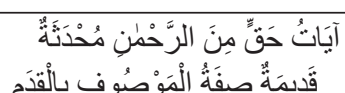 \\
\hline
\end{tabular}

Hemān Kurur'ān'da elfāẓıyla muḥdes olmışdur ${ }^{15}$

Veli ma nāsıdur vaṣf-1 ḳadīmi ẓāt-ı raḥmānı

92

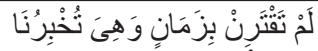

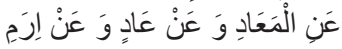

Zamāna muḳterin olmamışiken ol ḩaber virdi

Bize 'Ād u İremle ${ }^{16}$ ḥaşr u neşr ü rūḥ cismānı

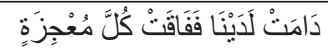

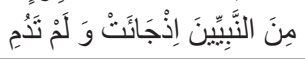

Tefevvuḳ eyledi āyātı i cāz-1 nebīyyīne

Ki mensūh itdigiçün hükmi anuñ cümle edyānı

14 Mısrada hece eksikliği sebebiyle vezin bozulmaktadır.

15 Misrada hece eksikliği sebebiyle vezin bozulmaktadır.

16 Metinde "İrem ile" yazmaktadır. Ancak vezin gereği "İremle" şeklinde okunmuştur. 


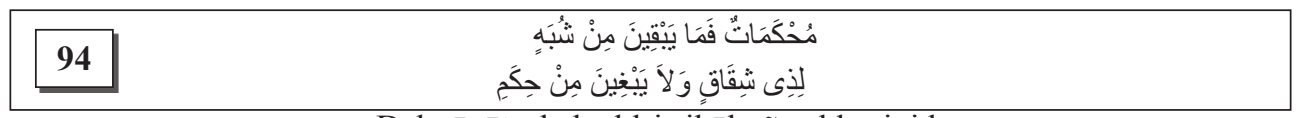

Daḩı āyāt-1 ḥaḳ ehl-i şiḳāḳuñ şübhesini ḳor

Yāhuūd muḥtāc ider mi ḥākime ol iki huașmānı

[39a]

\begin{tabular}{|c|c|}
\hline 95 & 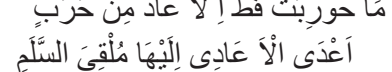 \\
\hline
\end{tabular}

Cidāliyle mu ādil olmadı illā rücū' itdi

Dönüp șulḥ u ṣalāḥ itdi ḳabūl eyledi fermānı

\begin{tabular}{|c|c|}
\hline 96 & 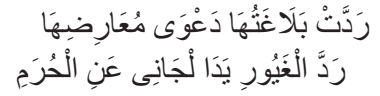 \\
\hline
\end{tabular}

Ve saḥbānıň kelāmını idüp red ol feșāḥatla

Serāyından nite bir mücrimi red itse sultānı

97

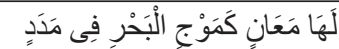

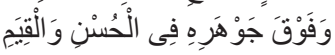

Deñiz mevcinden anuñ çünki artıḳ oldı ma nāsı

Dahıı hüsn bahāsını șebt ider lü' lü' -i 'ummānī

\begin{tabular}{|c|c|}
\hline 98 & 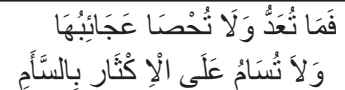 \\
\hline
\end{tabular}

Șayılmaz çünki Kuru'ān’uñ 'acībi gelmez iḥ̣āya

Melāmet virmez ammā gice gündüz oḳısañ anı

\begin{tabular}{|c|c|}
\hline 99 & 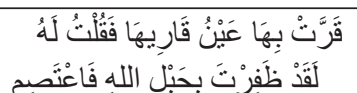 \\
\hline
\end{tabular}

Münevver gözlerin rūşen didim ḳārīi Kur ān'a

İrişdüñ ḥabl-i Bārī’ ye șaḳın elden ḳoma anı

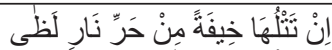

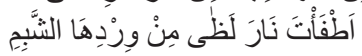

Lezānuñ nār-1 ger[min]i def' içün oḳısañ hergiz

Anuñ ol mā-i berdi ile iṭfā eyledüñ anı

101010

Belī Kur ān 'aẓīm gūyā ki ol bir havż-1 kevșerdir

Vücūda ... ${ }^{17}$ âhiretde ide nūrāni 


$$
\begin{aligned}
& \text { وَكَالصِّرَ اطِ وَكَالْمِيزَ انَ مَعْدِلَةً } \\
& \text { فَالْقِسنطُ مِنْ غَبْرِ هَا فِى النَّاسِ لَمْ يَقُمِ }
\end{aligned}
$$

'Adāletde țarịk-i müstaḳīme beñzedi gūyā

\begin{tabular}{|c|c|}
\hline 103 & 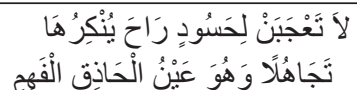 \\
\hline
\end{tabular}

Hidāyetle ḍalāluñ oldı ḥaḳka fażl-ı mīzānı

Bilür Kur'ān'uñ ol mu ciz idügiñ līk münkirdür

Hasūdındandır ol ammā ki vardur 'aḳl u iẓ'ānı

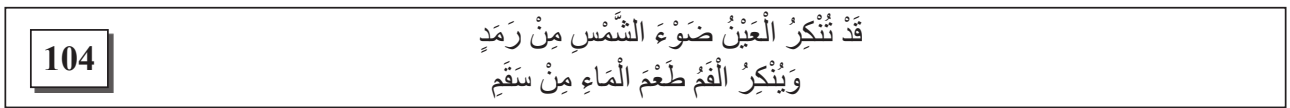

Remedden göz ṣınur yoḳdur żiyāsı şems-i tābānı

\begin{tabular}{|c|c|}
\hline 105 & 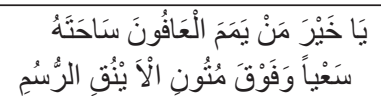 \\
\hline
\end{tabular}

Seḳamdan münkir olur ța 'm u āba ḩastenüñ cānı

Eyā şol 'āfiyet bulanlaruñ meşhūr [u] ma 'rūfı

Oḳurlar ümmetüñ sā'illeri ḳā'ilde dermānı

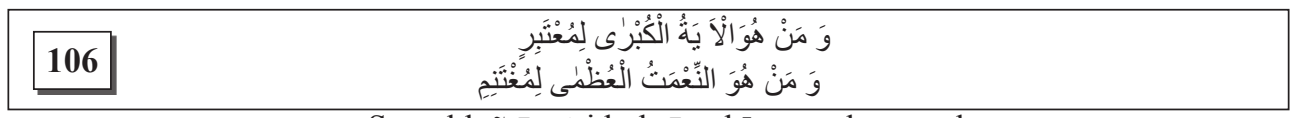

Sen olduñ āyet-i kübrā nebī mürsel arasında

Sen olduñ āyet-i 'uzmā-1 aṣḥāba ganīmānı

107

Haremden Mescid-i Aḳ̣̂ā'ya geldüñ bir gice nāgāh

Mișal-i bedir-āsā țayy idüp bu kevn ü imkānı

\begin{tabular}{|c|c|}
\hline 108 & 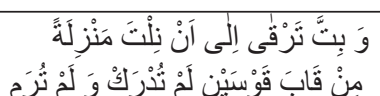 \\
\hline
\end{tabular}

[40a]

Ki sen bir menzile irdüñ o gice hiç eḥad anı

\begin{tabular}{|c|c|}
\hline 109 & 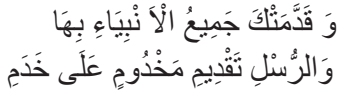 \\
\hline
\end{tabular}

Ne bildi ne taleb itdi ne urdı anda cevlānı

Cemī'-i enbiyā anda seni taḳdīm idüp ol şeb

Nice taḳdīm ider ise hadem mahdūm-1 sulțānı 


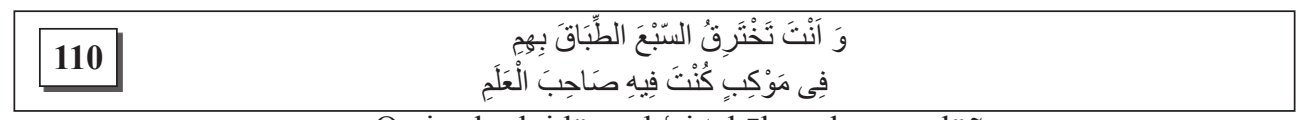

O gice harḳ idüp seb -i tabāk1 anları geçdüñ

Şu cem iyyet kim ol gice sen olduñ anlaruň cānı

\begin{tabular}{|c|c|}
\hline 111 & 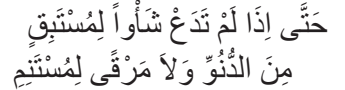 \\
\hline
\end{tabular}

Ki sābıḳlar içün ḥattā nihāyet ḳomaduñ aṣlā

Șu ūd idüp taḳarrübden teraḳḳī bula imkānı

\begin{tabular}{|c|c|}
\hline 112 & 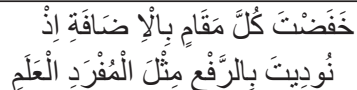 \\
\hline
\end{tabular}

Çıḳup ḥıfẓ eyledüñ anda nice a lā maḳāmātı

Nidā itdükde ref' ile seni ol luṭf-1 subhạnı

\begin{tabular}{|c|c|}
\hline 113 & 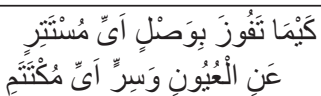 \\
\hline
\end{tabular}

Maḳām-1 vașla irüp bile idüm dir idüñ anı

Bu halḳuñ gözlerinden ketm olan ol sırr-1 pinhānı

\begin{tabular}{|c|c|}
\hline 114 & 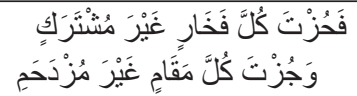 \\
\hline
\end{tabular}

Hुavāṣ-1 mu 'cizi cem ' eyledüñ bī-müşterek anda

Maḳām-1 enbiyā[yı] geçdüñ itdüñ anda seyrānı

[40b]

115

Merātibden yüce oldı saña i țā olan menzil

Ni 'amdan pes 'azìz oldı saña ol ḳurb-1 yezdānī

\begin{tabular}{|c|c|}
\hline 116 & 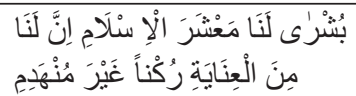 \\
\hline
\end{tabular}

Size yā ma 'şere'l-İslām beşāret müjdeler olsun

Yı̣ıılmaz ḩāne-i İslām var iken penc erkānı

Mükerrem eylediyse Haḳ habībiñ enbiyāsından

N'ola ikrām iderse ümmetine Rabb-i raḥmānī 


\begin{tabular}{|c|c|}
\hline 118 & 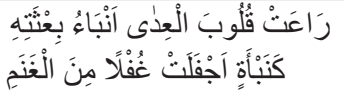 \\
\hline
\end{tabular}

Resūl'üñ bi śseti a dā-yı dīne ḳorḳular virdi

Ki şol șūret-i hafìyle reme ürkine mişān̄i

\begin{tabular}{|c|c|}
\hline 119 & 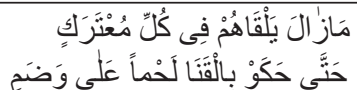 \\
\hline
\end{tabular}

Gazāda nīzeler üzre țaḳuben laḥm-1 küffārı

Kanāre ẓan iderdüñ sen eger görseñ o meydānı

\begin{tabular}{|c|c|}
\hline 120 & 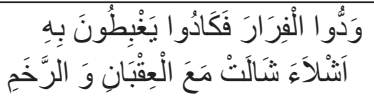 \\
\hline
\end{tabular}

Sürerlerdi firārı ġbṭa idüp dirler idi kim

Şu çengālinde 'uḳābuñ olaydık lạ̣m-1 zādānı

[41a]

\begin{tabular}{|c|c|}
\hline 121 & 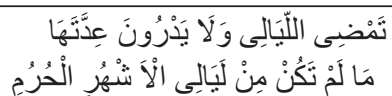 \\
\hline
\end{tabular}

'Umūm-1 ġamlarından rūz şeb hiç 'add olunmaz $<$ da $>$ mı

Meger kim eşher-i ḥurmuñ olınca vaḳt ü ezmānı

\begin{tabular}{|c|c|}
\hline 122 & 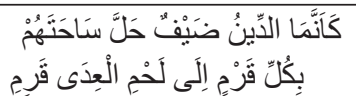 \\
\hline
\end{tabular}

Ki gūyā cāy-1 küffāra oluben bu hạk ${ }^{18}$

Lühūmı kāfire mā' ildür seyyid-i a 'ẓam olanı ${ }^{19}$

\begin{tabular}{|c|c|}
\hline 123 & 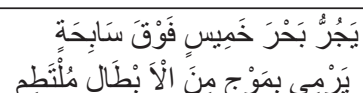 \\
\hline
\end{tabular}

Süvār olup deñizler 'asker çekdi ol seyyid ${ }^{20}$

Atarlardı biri bir üzre cümle kāfir olanı

Ol erler kim işiñ Allāh içün ḩāliṣ ḳılanlardur

Kim anlar küfr[i] ḳaṭ itdi mu'āvin dutdı Kur ân’’1

18 Misrada hece eksikliği sebebiyle vezin bozulmaktadır.

19 Misrada vezin bozulmaktadır.

20 Mısrada hece eksikliği sebebiyle vezin bozulmaktadır. 


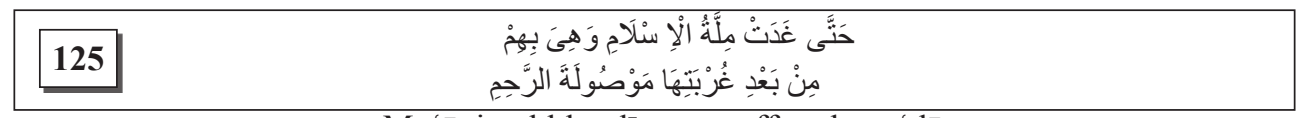

Mu'āvin oldılar dīne muẓaffer olup a dāya

Şeref buldı garīib oldıḳlarından ṣoñra edyānı

\begin{tabular}{|c|c|}
\hline 126 & 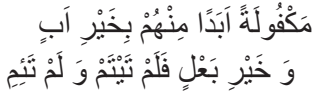 \\
\hline
\end{tabular}

Kefillendi o hayr-1 āb ile bu millet-i İslām

Yetīm ü bīve ḳalmadı ebed ol zevcüñ olanı

\begin{tabular}{|c|c|}
\hline 127 & 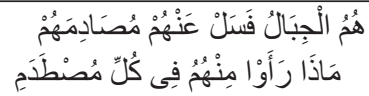 \\
\hline
\end{tabular}

Pes anlardan su'āl eyle o țag̉lar gibi 'askerden

Kim a 'dāya neler itmişdür İslām'uñ şücā'ānı

[41b]

\begin{tabular}{|c|c|}
\hline 128 & 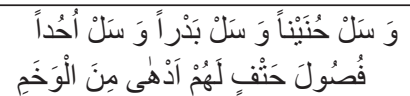 \\
\hline
\end{tabular}

Huneyn ü Bedr Uḥud ehlinden anı sen su'āl eyle

Vebādan artıḳ oldı anlara edhā vü vehmānı

\begin{tabular}{|c|c|}
\hline 129 & 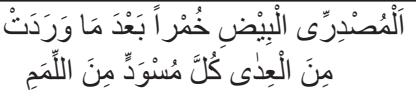 \\
\hline
\end{tabular}

Bahādırlar ḳılıçların ḳızıl ḳana boyarlardı

'Adūnuñ vaḳresine uruban şemşīr-i bürrānı

\begin{tabular}{|c|c|}
\hline 130 & 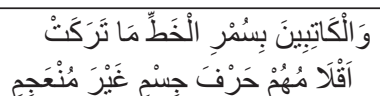 \\
\hline
\end{tabular}

Nüvīsān-1 ġazā bir hat yazardı cism-i küffāra

Süñüler birle sürhile ḥurūf-ı bì-nuḳațānı

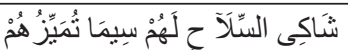

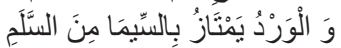

Ṣalāḥ ü hem silāḥ ile bular mümtāz idi gūyā

Nice mümtāz-şān kim Selem'den verd-i ḩandānı

Saña bād-1 șabā ihdā ideydi bunlaruñ ṭıybın

Çiçekler içre anlar ġonce güldür dir idüñ anı 
[42a]

133

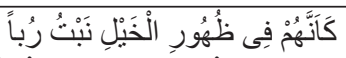

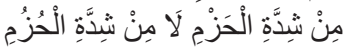

Ki gūyā atlaruñ üstine berk olmuş şecerlerdür

Aña bā' is degil esbāb-1 esb-i farṭ-1 rahtānı

\begin{tabular}{|c|c|}
\hline 134 & 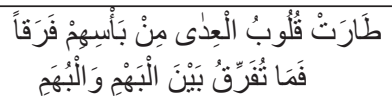 \\
\hline
\end{tabular}

'Adūnuñ ḳalbine şöyle düşerdi heybet-i İslām

Ki tā farḳ itmez oldılar behā'imden behīmānı

135

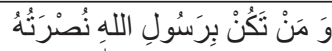

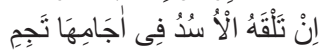

Resūlullāh mu'āvin olduġına hịç żarar irmez

Eger ohşasa incitmez yanında yatan arslanı

\begin{tabular}{|c|c|}
\hline 136 & 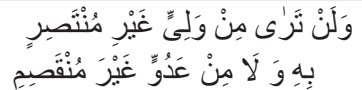 \\
\hline
\end{tabular}

Anuñ yoḳ aṣdiḳāsından ki manșūr olmamış ola

Bulunmaz hem 'adūsından ki maḳhūr itmeye anı

137

$$
\begin{aligned}
& \text { اَحَلَّ أُمَنََهُهُ فِى حِزْز مِلَّتِهِ }
\end{aligned}
$$

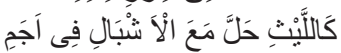

Hiṣār-1 emn-i millet içre ḳodı ümmetini ol

Şu sīn-āsā ki buldı beççesine cāy-ı gāaānı

138

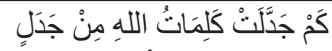

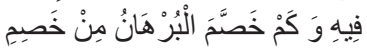

Kelām-1 Haḳ nice ehl-i cidāle gāālib oldıysa

Resūl'üñ mu'cizātı dahı red itdi lecūcānı

$$
\begin{aligned}
& \text { كَفَالكَ بِالْعِلْمِ فِى الْالِّْىِ مُعْجِزَةً }
\end{aligned}
$$

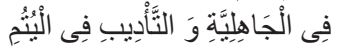

Anuñ ümmīligi hạālinde olan hulḳ u hașletler

Yeter mu 'ciz saña ādāb 'ilmi ile bürhānı

[42b]

$$
\begin{aligned}
& \text { خَذَمْنُهُ بِمَدِيح اَسنتقَقِيلُ بِهِ }
\end{aligned}
$$

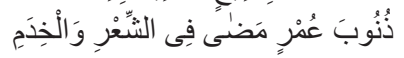

Bu medḥ ile zünūb-1 sābıḳuñ 'afvüñ ricā itdüm

Şu ‘ömri kim geçürdüm naẓm-1 ḩıdmetde mülükānı 


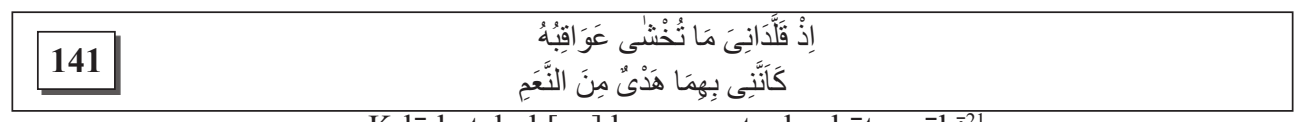

Ḳılāde țaḳub[en] boynıma țavḳ-1 hāạtır-nākīi ${ }^{21}$

Ki gūyā hedy içün oldum nişānlanmış behīmānı

\begin{tabular}{|c|c|}
\hline 142 & 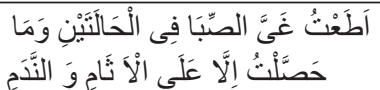 \\
\hline
\end{tabular}

Muțī‘ olmag̉ıla nefse ḍalālet cāhına düşdüm

Ki tahșịil itmedüm illā nedāmāt u zünūbānı

\begin{tabular}{|c|c|}
\hline 143 & 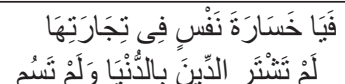 \\
\hline
\end{tabular}

Hasāret nefsimüñ dā'im ticāretle ziyānātı

Virüp dünyāyı niçün itmedüm maḳṣūd-1 cānānı

144

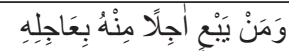

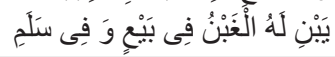

O kim bey itdi uhrāȳ bu dünyā-yı den̄i içün

O gabn-i fāḥişüñ āhir olur çoḳ çok peşīmānı

145

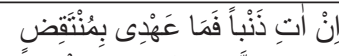

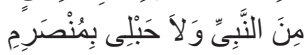

Eger sehv ü hațā iderisem șaymazam 'ahidüñ

Komam elden anuñ şer'-i şerīüuñ hü̈km-i Ķur'ān'1

\begin{tabular}{|c|c|}
\hline 146 & 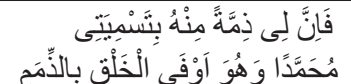 \\
\hline
\end{tabular}

[43a]

Semiyy olmagile ben anuñ 'ahd ü emān oldum ${ }^{22}$

\begin{tabular}{|c|c|}
\hline 147 & 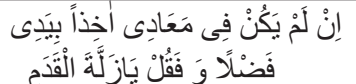 \\
\hline
\end{tabular}

Anuñ ise vefā-i va'desinde yoḳdur aḳrānı

Yapışmazsa elimden rūz-1 maḩşerde kerem idüp

Ve illā diyesiz yā zellete'l-aḳdām 'iṣyānı

148

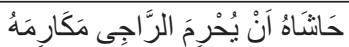

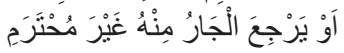

Ki ḥāşā zạât-1 ḩalḳıında ki bir rācī ola maḥrūm

Husụūṣā kim döne mi muḥterem aṣhāb-ı ḥayrānı

21 Misrada vezin bozulmaktadır.

22 Misrada vezin bozulmaktadır. 


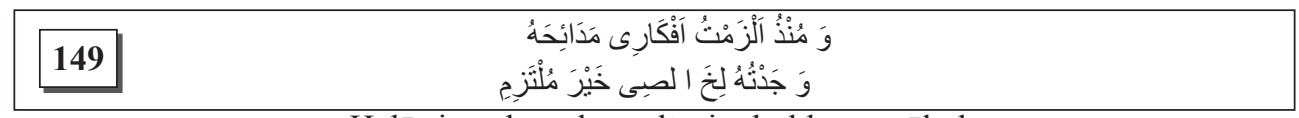

Ḩalāṣ içün hayirlu mültezim buldum o şāhı ben

Anuñ șarf ideli medḥine küllü 'aḳl u iẓ ānı

\begin{tabular}{|c|c|}
\hline 150 & 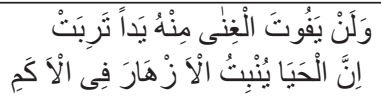 \\
\hline
\end{tabular}

Nehy olmadı ġınā-yı ni 'metinden dest-i dervīşüñ

Ekemde niyyet inbāt eylese bārān nebātānı

\begin{tabular}{|c|c|}
\hline 151 & 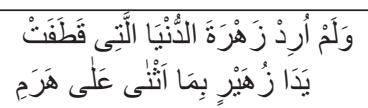 \\
\hline
\end{tabular}

Bu medhile velī dünyā meta 'iñ itmedüm maḳṣūd

Züheyir şā irüñ oldug̉ı gibi ibn-i ḥubbānī

152

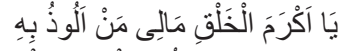

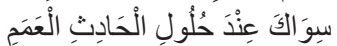

Benüm ey server-i 'ālem melāz u melce' im ol sen

Ki ya 'nī hạalet-i nez' de hăaliṣ itmekde ìmānı

[43b]

153

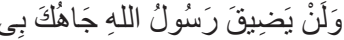

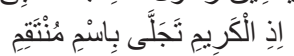

Bu 'abdüñ intisābıyla senüň ḳadrine naḳs irmez

\begin{tabular}{|c|c|}
\hline 154 & 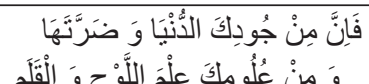 \\
\hline
\end{tabular}

Bu dem kim ol kerīm ahẓ eyleye bu 'abd-i giryānı

Bu dāreynüñ ḥuṣūli vü vușūli baḥr-i cūduñdur

'Ulūmından ḳalem ketb eyledi levḥ üzre Kur'ān'1

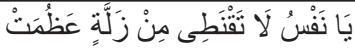

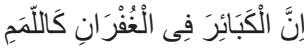

Buyurmışdur ki Hạ lā taḳnețū min raḥmetillāhi

Kebā'irde olursa mạ̣v ider ol baḥr-1 gufrānı

Umarum hażret-i Rabb raḥmetini ḳısmet itdükde

'İbādınuñ zunūbına göre ol ḳıla erzānī 


\begin{tabular}{|c|c|}
\hline 157 & 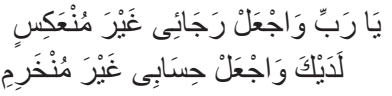 \\
\hline
\end{tabular}

Hüdāvendā recā ümmīdimi 'aks itme luṭ̂ndan

Müyesser ḳ1l virmek hisābı sehl-i āsāni $\bar{i}^{23}$

\begin{tabular}{|c|c|}
\hline 158 & 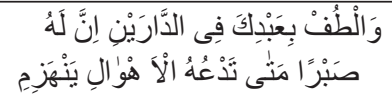 \\
\hline
\end{tabular}

Baña dünyāda ve 'uḳbāda luṭf eyle eyā yā Rabb

Ki zīrā ḳorḳulu yerler șabır olur hezīmānı

[44a]

\begin{tabular}{|c|c|}
\hline 159 & 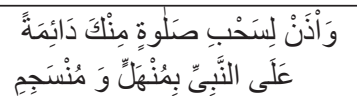 \\
\hline
\end{tabular}

Seḥāb-1 raḥmete emr eyle her demde nișār itsün

Resūl-i bā-ṣafānuñ üstine bārān-ı iḥsānı

\begin{tabular}{|c|c|}
\hline 160 & 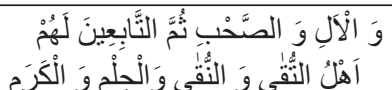 \\
\hline
\end{tabular}

Daḥı aṣhāb u āline naḳiyy-i tābi īne hem

Ṣalāt ile selām olsun kim anlardur kerem-kānı

161

$$
\begin{aligned}
& \text { مَا رَنَََّتْ عَذَبَاتِ الْبَانِ رِيحُ صَبَّا }
\end{aligned}
$$

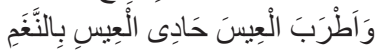

Șabā gülşende taḥīk eyledükçe 'aẓbe-i bānuñ

Her ațrāb eyledükçe 'iys-i ḥādīi hoşşühānı

Ola rūḥ-1 Resūlullāh'a șad gūne tahiyyetler

Ki Zāâ̄i haḳịiüñ yoḳdur andan gàrı dermānı ${ }^{24}$

Hakem Değerlendirmesi: Dış bağımsız.

Çıkar Çatışması: Yazar çıkar çatışması bildirmemiştir.

Finansal Destek: Yazar bu çalışma için finansal destek almadığını beyan etmiştir.

Peer-review: Externally peer-reviewed.

Conflict of Interest: The author has no conflict of interest to declare.

Grant Support: The author declared that this study has received no financial support.

23 Misrada hece eksikliği sebebiyle vezin bozulmaktadır.

24 Bu beytin kaynak metinde karşılığı yoktur. 


\section{KAYNAKÇA/REFERENCES}

Albayrak Sak, V. (2014). Şemseddin Sivâsî’nin kasîde-i bürde tercümesi. Turkish Studies. 9,(3), 91-110. Armutçuoğlu, İ. (2009). Kasîde-i bürde. İstanbul: Erkam Yayınları.

Armutlu, S. (2018). Zâtî: Hayatı, kişiliği, sanatı ve eserleri. Atatürk Üniversitesi Sosyal Bilimler Enstitüsü Dergisi. 22 (Özel Say1), 1935-1956.

Armutlu, S. (1998). Zâtî’nin şem ü pervânesi (inceleme-metin). (Doktora Tezi). İnönü Üniversitesi Sosyal Bilimler Enstitüsü, Malatya.

Arslan, M. (1994). Zâtî Süleyman Efendi - dîvân ve sevânihu'n-nevâdir fì ma'rifeti 'l-anâsır. Sivas: Dilek Matbaacilik.

Arslan, M. (2014). Zâtî, Süleymân Efendi. Türk edebiyatı isimler sözlüğü içinde. Erişim adresi: http://teis. yesevi.edu.tr/madde-detay/zati-suleyman-efendi

Ayçiçeği, B. (2015). Bûsîrî (ö. 696/1297 ?)'nin Kasîdetü'l-Bürde'sinin Diyarbakırlı Mehmed Said Paşa (ö. 1308/1892) tarafından yapılan mensur ve manzum tercümesi. Divan Edebiyatı Araştırmaları Dergisi. (15), 27-102.

Ayçiçeği, B. (2016). Üsküdarlı Abdülhay Celvetî ve kasîde-i bürde tercümesi. 9. Uluslararası Üsküdar Seтроzyuтu (11-13 Kasım 2016) Bildiriler C. II içinde, s. 223-266. İstanbul: Üsküdar Belediyesi Yayınları.

Ayçiçeği, B. (Proje Yöneticisi). (2018). Bûsirî’nin Kasîde-i Bürde sinin geçmişten günümüze türkiye toplumu üzerindeki akademik, sosyal ve dini etkileri. (Tamamland1: 15.05.2016-20.09.2018). TÜBITAK Projesi, Proje nu.: 215K398.

Ayçiçeği, B. (2020). Necîb Efendi'nin Kasîde-i Bürde Şerhi: Muhtasar tevessül (inceleme-tevessül'le karşılaştırma-metin). İstanbul: Dün Bugün Yarın Yayınları.

Cankurt, H. (2014). Seyyid Hasan Rizâyî el-Aksarâŷ̂ hayâtı, sanatı, eserleri ve Miftâhu's-Sa'âde" adlı Manzum Kasîde-i Bürde şerhi. (Yüksek Lisans Tezi). Celal Bayar Üniversitesi Sosyal Bilimler Enstitüsü, Manisa.

Çavuşoğlu, M. (1970). Zâtî̀nin letâyifi. IÜ. Edebiyat Fakültesi Türk Dili ve Edebiyatı Bölümü Dergisi. $18,25-51$.

Çavuşoğlu, M. (1977) Zâtî’nin letâyifi II. İÜ. Edebiyat Fakültesi Türk Dili ve Edebiyatı Bölümü Dergisi, 22, 143-161.

Çavuşoğlu, M. ve Tanyeri, M. A. (1987). Zâtî Divanı - gazeller kısmı III. Cilt Edisyon Kritikve Transkripsiyon. İstanbul: İstanbul Üniversitesi Edb. Fak. Yay.

Coşkun, V. (2013). Zâtî. TDV İslâm ansiklopedisi içinde (C. 44, s. 150-151). İstanbul: Türkiye Diyânet Vakfi Yayınları.

Demirayak, K. (2001). Kasîdetü'l-Bürde. TDV İslâm ansiklopedisi içinde (C. 24, s. 566-568). İstanbul: Türkiye Diyânet Vakfi Yayınları.

Ertaylan, İ. H. (1960). Abdürrahim Karahisarî, Tercüme-i Kasîde-i Bürde. İstanbul: İstanbul Üniversitesi Edebiyat Fakültesi Yay.

Günaydın, Y. T. (1995). İbn-i Kemâl edebî kişiliği ve kasîde-i bürde Tercümesi (Tenkitli Metin). (Basılmamış Yüksek Lisans Tezi). Ankara Üniversitesi Sosyal Bilimler Enstitüsü, Ankara.

Harman, Ö. F. (2004). Âbidin Paşa, kasîde-i bürde tercümesi ve şerhi. İstanbul: Kalem Yayınları.

İlhan, M. (2017). Na’îmî’nin Manzum Kaside-i Bürde Tercümesi. Littera Turca. 3(4), 42-61.

Kahraman, B. (1997). Le'âlî ve Abdurrahîm Karahisârî’nin manzum kasîde-i bürde tercümeleri. Selçuk Üniversitesi Türkiyat Araştırmaları Dergisi. 4, 57-107. 
Karaca, D. (2018). Zâtî’nin Edirne şehrengizi. Uluslararası Sosyal Araştırmalar Dergisi. 11(55), 114-136. Karadeniz, M. (2010). Heft-Peyker (inceleme-metin). (Yüksek Lisans Tezi). Dicle Üniversitesi Sosyal Bilimler Enstitüsü, Diyarbakır.

Kaya, M. (1992). Bûsîrî, Muhammed b. Saîd. TDV İslâm Ansiklopedisi içinde (C. 6, s. 468-470). İstanbul: Türkiye Diyânet Vakfı Yayınları.

Koç, H. (2018). Ahmed-i Rıdvan'ın manzum kasîde-i bürde tercümesi. Osmanlı Mirası Araştırmaları Dergisi. 5(12), 9-31.

Kurtoğlu, O. (2013). Zâtî, Ivaz. Türk Edebiyatı İsimler Sözlüğü içinde. Erişim adresi: http://teis.yesevi. edu.tr/madde-detay/zati-ivaz

Kurtoğlu, O. (2017). Zâtî divanı (gazeller dışındaki şiirleri) e-kitap. (Erişim Târihi: 15.04.2020). Ankara: T.C. Kültür ve Turizm Bakanlığı Kütüphaneler ve Yayımlar G. M. Kültür Eserleri Dizisi-552.

Kut, G. (1973-74). Gazâlı’’nin Mekkke’den İstanbul'a Yolladığı Mektup ve Ona Yazılan Cevaplar. Türk Dili Araştırmaları Yıllığı Belleten. TDK Yay. s. 223-252.

Kuzubaş, M. (2007). Muhammed Fevzî’nin Miftâhu'n-Necât Adlı Eseri. Uluslararası Sosyal Araştırmalar Dergisi. 1(1), 156-192.

Omay, A. (2001). Zâtî Süleyman efendi, miftahü'l-mesâ'il. (Yüksek Lisans Tezi). Ege Üniversitesi Sosyal Bilimler Enstitüsü, İzmir.

Saraç, M. A. Y. (1994). Kemal Paşazâde'nin Manzum Kasîde-i Bürde Tercümesi. İslâmi Edebiyat. (24), 65-70.

Sezer, İ. H. (1985). Şâir Bûsirîve Bürde si. (Basılmamış Doktora Tezi). Selçuk Üniversitesi Sosyal Bilimler Enstitüsü, Konya.

Şahin, E. S. (1997). Kasîde-i Bürde’nin Türkçe şerh ve tercümeleri. (Basılmamış Yüksek Lisans Tezi). Gazi Üniversitesi Sosyal Bilimler Enstitüsü, Ankara.

Şimşek, S. (2010). Süleymân Zâtî. TDV İslâm Ansiklopedisi içinde (C. 38, s. 110-111). İstanbul: Türkiye Diyânet Vakfi Yayınları.

Şimşek, S. (2005). Keşanlı Süleymân Zâtî ve XVIII. Asırda celvetîlik. (Doktora Tezi). Atatürk Üniversitesi Sosyal Bilimler Enstitüsü, Erzurum.

Tarlan, A. N. (1967). Zâtî Divanı- gazeller kısmı I. Cilt "edisyon kritik ve transkripsiyon. İstanbul: İstanbul Üniversitesi Edebiyat Fakültesi Yayınları.

Tarlan, A. N. (1970). Zâtî Divanı - gazeller kısmı II. Cilt "edisyon kritik ve transkripsiyon. İstanbul: İstanbul Üniversitesi Edebiyat Fakültesi Yayınları.

Ünver, N. (2007). Zâtî. Türk dünyası edebiyatçıları sözlüğ̈̈ içinde (C. 8, s. 710-712). Ankara: Atatürk Kültür, Dil ve Tarih Yüksek Kurumu Atatürk Kültür Merkezi Yayınları.

Yazar, S. (2011). Anadolu sahası klasik türk edebiyatında tercüme ve şerh geleneği. (Doktora Tezi). İstanbul Üniversitesi Sosyal Bilimler Enstitüsü, İstanbul. 


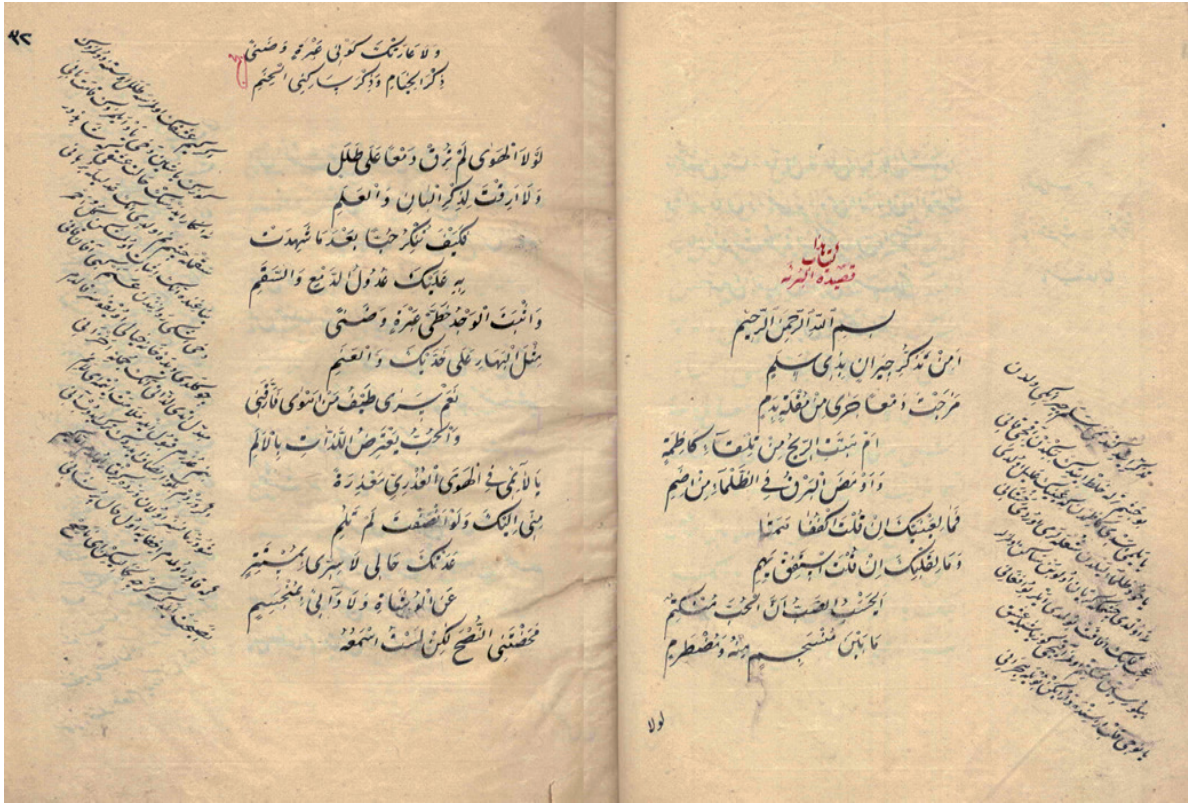

$31 b$ - 32a

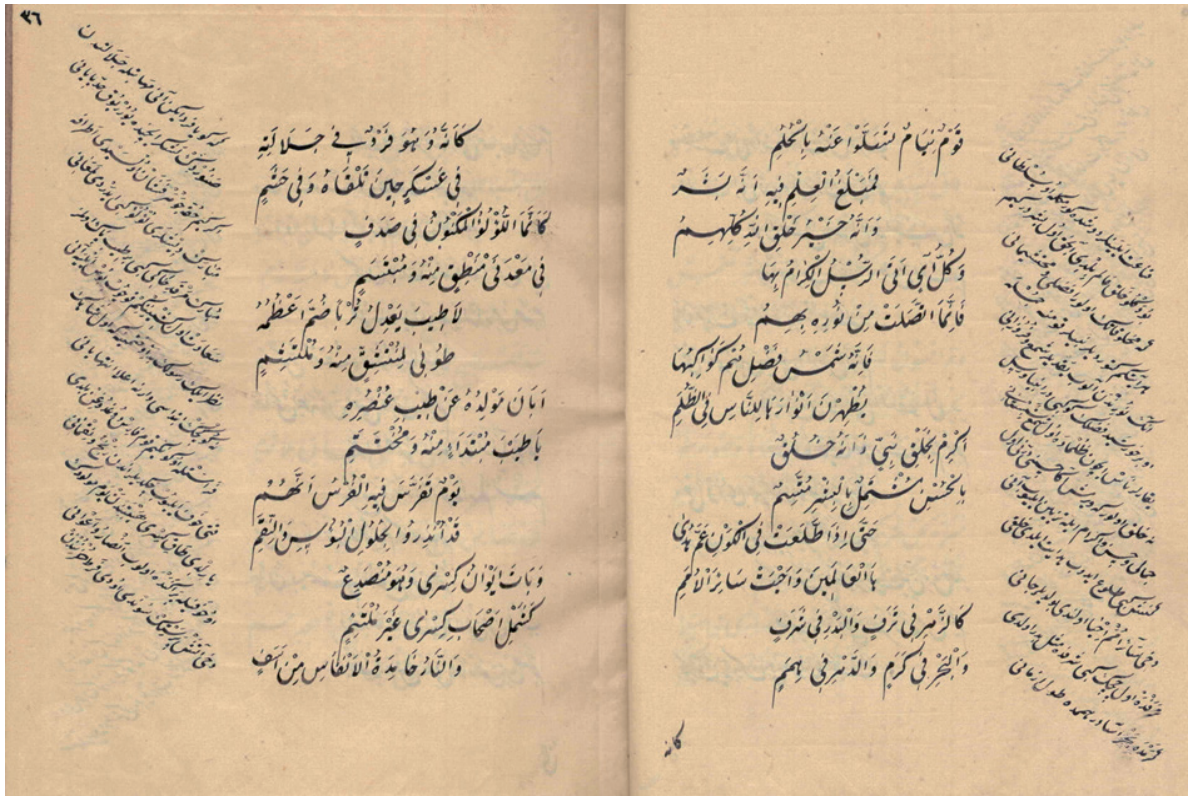

$35 b-36 a$ 


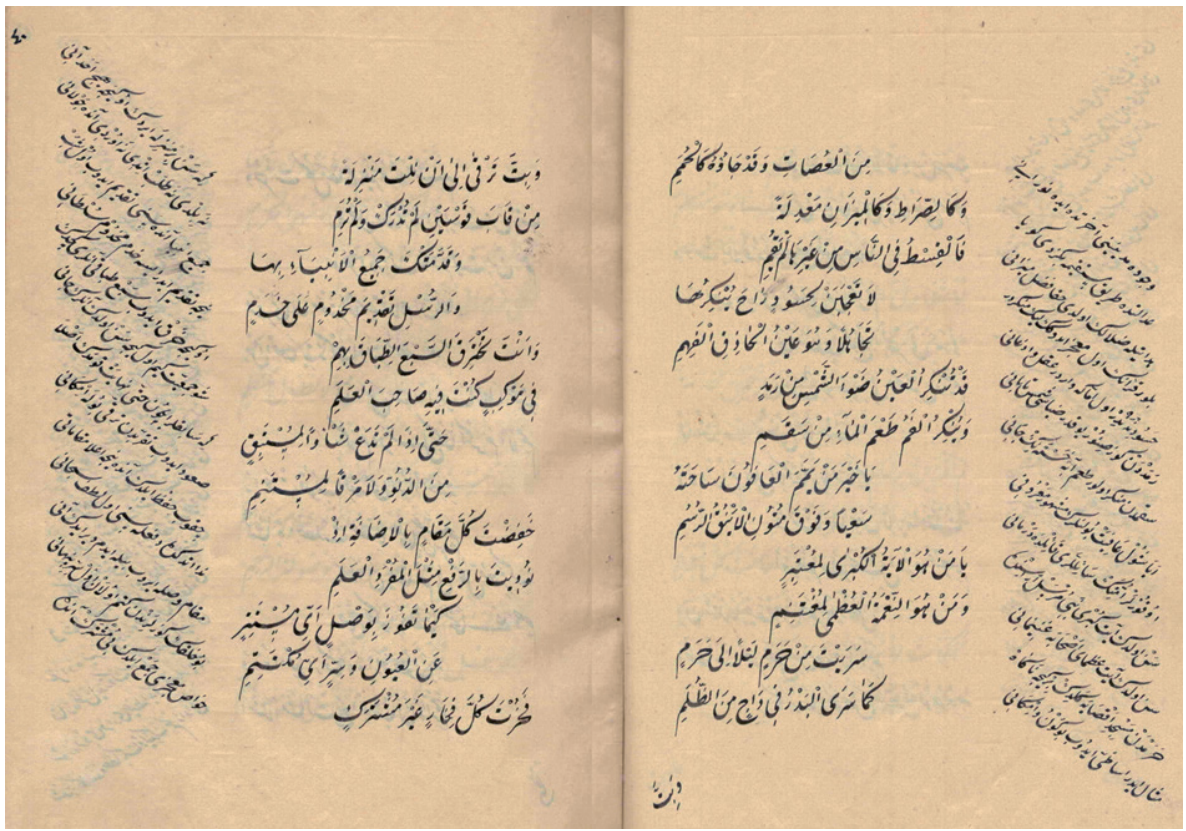

$39 b-40 a$

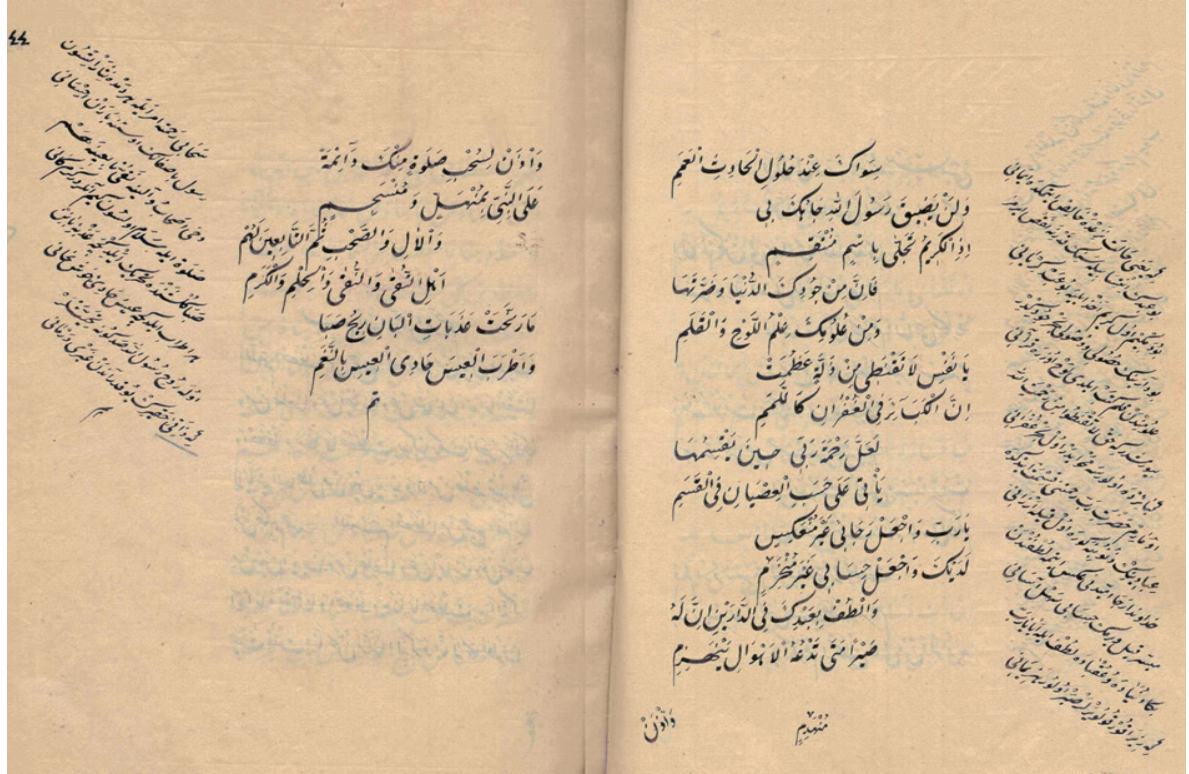

$43 b-44 a$ 